\title{
Scoping Study of Integrated Resource Planning Needs in the Public Utility Sector
}

C. J. Garrick

J. M. Garrick

D. R. Rue

NEOS Corporation

Lakewood, Colorado

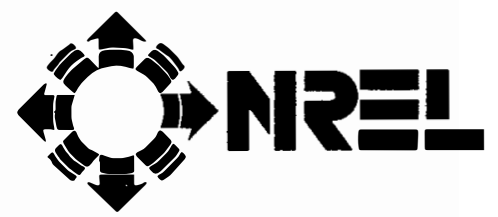

National Renewable Energy Laboratory A Division of Midwest Research Institute Operated for the U.S. Department of Energy Under Contract No. DE-AC02-83CH10093 


\section{Scoping Study of Integrated Resource Planning Needs in the Public Utility Sector}

NREL Technical Monitor: B. Swezey

C. J. Garrick

J. M. Garrick

D. R. Rue

NEOS Corporation

Lakewood, Colorado

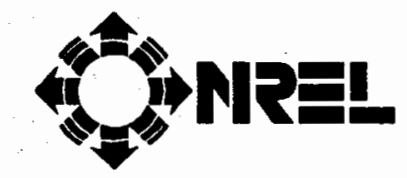

National Renewable Energy Laboratory

(formerly the Solar Energy Research Institute)

1617 Cole Boulevard

Golden, Colorado 80401-3393

Operated for the U.S. Department of Energy

by the Midwest Research Institute

under Contract No. DE-AC02-83CH10093

Prepared under Task No. AS1 15440

June 1993 


\section{NOTICE}

NOTICE: This report was prepared as an account of work sponsored by an agency of the United States government. Neither the United States government nor any agency thereof, nor any of their employees, makes any warranty, express or implied, or assumes any legal liability or responsibility for the accuracy. completeness, or usefulness of any information, apparatus, product, or process disclosed, or represents that its use would not infringe privately owned rights. Reference herein to any specific commercial product, process, or service by trade name, trademark, manufacturer, or otherwise does not necessarily constitute or imply its endorsement, recommendation, or favoring by the United States government or any agency thereof. The views and opinions of authors expressed herein do not necessarily state or reflect those of the United States government or any agency thereof.

\section{Printed in the United States of America \\ Available from:}

National Technical Information Service

U.S. Department of Commerce

5285 Port Royal Road

Springfield, VA 22161

Price: Microfiche A01

Printed Copy A05

Codes are used for pricing all publications. The code is determined by the number of pages in the publication. Information pertaining to the pricing codes can be found in the current issue of the following publications which are generally available in most libraries: Energy Research Abstracts (ERA); Government Reports Announcements and Index (GRA and I); Scientific and Technical Abstract Reports (STAR); and publication NTIS-PR-360 available from NTIS at the above address. 


\section{Acknowledgments}

A number of individuals provided input to and assistance on this scoping study. These contributions are greatly appreciated. The following individuals served as peer reviewers for the draft study report: Michael Arny of the Wisconsin Public Service Commission, Mike Bull of the Bonneville Power Administration, Rob Church and Mike Oldak of the National Rural Electric Cooperative Association, Clarence Council of the Western Area Power Administration, Barry Moline of the American Public Power Association, and Georg Shultz of the Rural Electrification Administration. Each of the 29 interview participants shared their experiences and contributed their individual perspectives regarding integrated resource planning needs in the public utility sector. However, the views presented in this report are those of the authors and do not necessarily represent the views of the contributors and reviewers. 


\section{Foreword}

This scoping study was sponsored by the U.S. Department of Energy's (DOE's) Integrated Resource Planning (IRP) Program and conducted by NEOS Corporation under subcontract to the National Renewable Energy Laboratory (NREL). The mission of the DOE's IRP program is "to develop and promote the adoption of IRP concepts and techniques in conjunction with the states, electric and gas utilities, consumers, interest groups, power marketing administrations, federal agencies, and other stakeholders to encourage greater competition, economic efficiency, and environmental quality in the utility sector."

The objectives for this study were to (1) profile the IRP-related characteristics of the public utility sector ${ }^{1}$, (2) identify the IRP practices and needs of these utilities, and (3) suggest strategies for IRP advancement in this utility sector. The scoping study was developed primarily as a discussion paper on IRP in the public utility sector, and will provide a basis for additional IRP advancement efforts in this utility sector.

This study provides an overall perspective of public utilities and their IRP-related activities and needs. However, the study does not fully reflect the extreme diversity and complexity of the public utility sector. Therefore, this scoping study, by its nature, presents a consolidated perspective of these utilities and their IRP situation. Further work is necessary before a comprehensive IRP advancement strategy for public utilities can be developed.

\footnotetext{
${ }^{1}$ As defmed for this study, public utilities include federal, state, municipal, and cooperative utilities. These utilities are often referred to by other names, including "publicly owned utilities" and "consumer-owned utilities." However, all of these names can be misleading or confusing because they do not accurately describe this diverse utility sector. For example, investor-owned utilities are commonly referred to as "public utilities" (i.e., private companies that act in the public good). Cooperatives, which make up a significant portion of this utility sector, are private corporations that are not publicly owned. In addition, many of these utilities (e.g., municipalities) are government-owned, rather than consumer-owned. For the purposes of this study, the term public utility is used to refer to this diverse utility sector because this terminology is in common use by DOE and others. However, the study sponsors and authors recognize that this term has limitations and that another designation, such as not-for-profit utility sector, might be more appropriate.
} 


\section{Summary}

Integrated resource planning (IRP) is an approach to utility resource planning that integrates the evaluation of supply- and demand-side options for providing energy services at the least cost. Although many utilities across the nation practice IRP, and considerable study has been applied to this subject, that activity and research has been focused almost exclusively on investor-owned utilities (IOUs). The purpose of this scoping study is to investigate the IRP-related activities and needs of public utilities. ${ }^{1}$ This study performs the following:

- Profiles IRP-related characteristics of the public utility sector

- Articulates the needs of public utilities in understanding and implementing IRP

- Identifies strategies to advance IRP principles in public utility planning.

Figure S-1 is an organization chart of U.S. electric utilities. It highlights the various entities comprising the public utility sector. As illustrated, the public utility sector can be categorized as "government-owned" (e.g., federal, state, municipal, joint action agency, and other) or "cooperatively owned" (e.g., generation and transmission cooperatives and distribution cooperatives) utilities. Although this sector is very diverse in comparison with the IOU sector, all public utilities can be distinguished by several key attributes. Public utilities are not-for-profit utilities. They are owned and/or controlled by the people they serve, and they receive preference access to federal hydroelectricity.

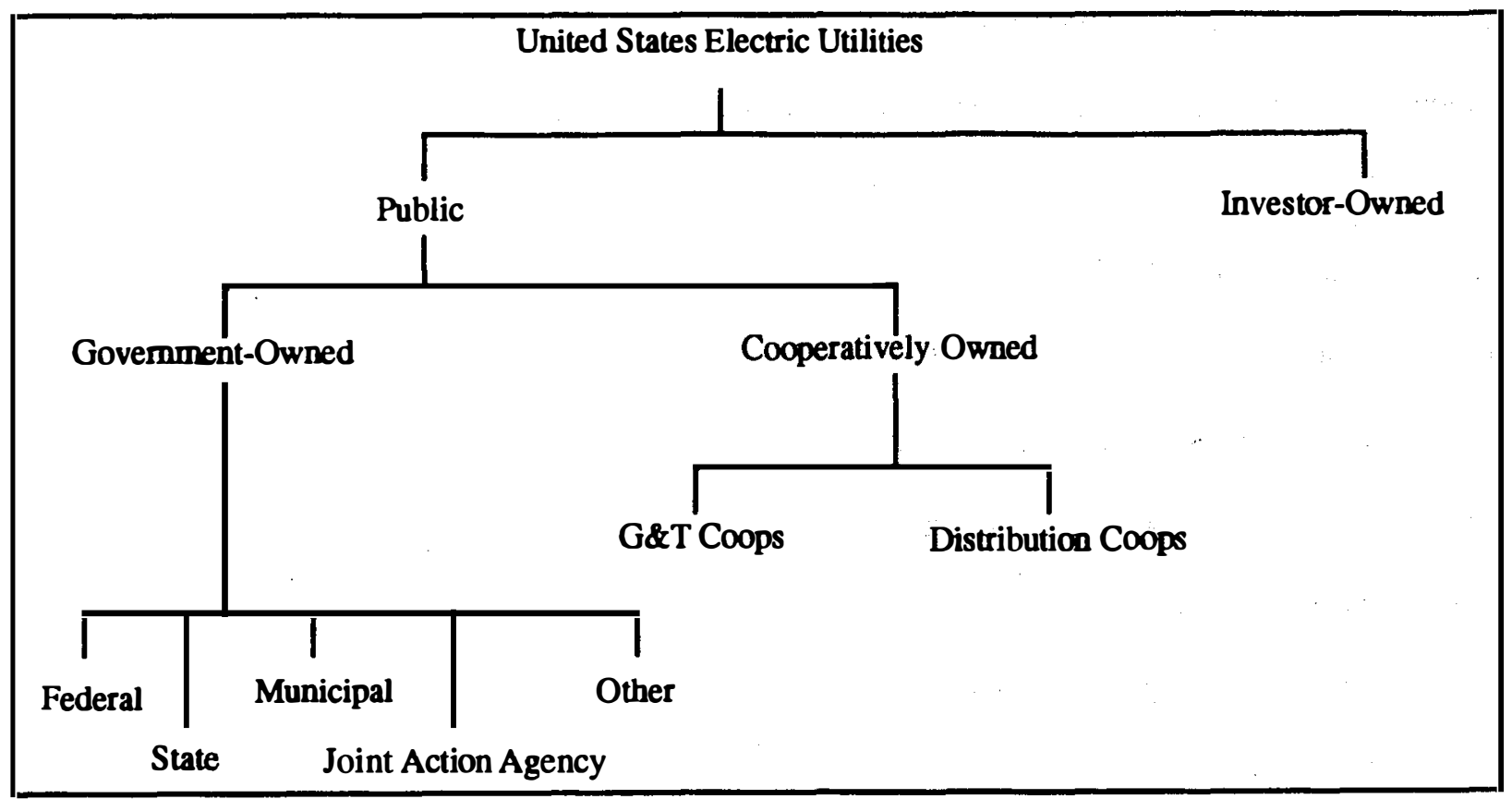

Figure S-1. Organization of U.S. electric utilities

${ }^{1}$ As defined for this study, public utilities refer to not-for-profit utilities that include federal, state, municipal, and cooperative utilities. Refer to the section entitled Profile of the Public Utility Sector and to Appendix A: Glossary of Terms for additional definitions and discussions on public utilities. 
In 1990, the 2971 public utility systems represented $92 \%$ of the nation's utilities; the 266 IOUs represented the other $8 \%$. However, the public utilities sold $25 \%$ of the country's electric energy; the IOUs sold the other $75 \%$. These statistics indicate that most of the country's IOUs are large companies, whereas the majority of the public utilities are considerably smaller systems.

The trend toward IRP has largely affected IOUs to date; however, it has also impacted public utilities. The most recognized example is the practice of IRP in the Pacific Northwest region served by the Bonneville Power Administration (BPA). According to information obtained from several national publicutility-oriented organizations, a number of public utilities currently practice IRP. Although some of this activity occurs in response to state public utility commission requirements, many of these public utilities conduct IRP on a voluntary basis. However, it appears that significantly fewer public utilities practice IRP than do IOUs.

As part of this study, a limited sample of public utilities was interviewed to gain additional insight into the IRP-related activities and needs of this utility sector. This study identifies four drivers behind public utility IRP activity:

(1) IRP is good fiscal business practice

(2) IRP is required by federal and state agencies

(3) IRP can address environmental considerations

(4) IRP provides a sound planning methodology.

Additionally, this study identifies eight barriers to greater IRP implementation:

(1) Nonintegrated organizational structures

(2) Lack of knowledge/experience

(3) Surplus electricity

(4) Limited financial and personnel resources

(5) Conservative boards and managers

(6) Unavailable/unreliable data

(7) Overlapping/conflicting regulations

(8) Mixed pricing signals.

Determination of the drivers and barriers were based on interviews, the authors' existing knowledge base on IRP in the public utility sector, and contacts with national public-utility-oriented organizations.

Considerable opportunity exists to advance IRP activity in the public utility sector. This study delineates seven specific strategies for building greater awareness and understanding and promoting implementation of IRP principles and practices in this utility sector: 
(1) Applied research

(2) Education and information dissemination services

(3) Technical assistance

(4) Methods and tools development

(5) Data development and transfer

(6) Financial assistance and incentives

(7) Regulatory mandates.

These strategies are tailored to the unique and diverse aspects of public utilities.

Figure S-2 indicates the applicability of each strategy for overcoming the eight identified barriers to greater IRP implementation. No single strategy is sufficient to fully advance IRP in the public utility sector-a combination of strategies is recommended to effectively address the various barriers. Even though a number of organizations are currently implementing many aspects of these strategies, the fact that most of the nation's public utilities do not practice IRP is evidence that the resources currently being applied to advance IRP in this sector are insufficient. 
TP-5473

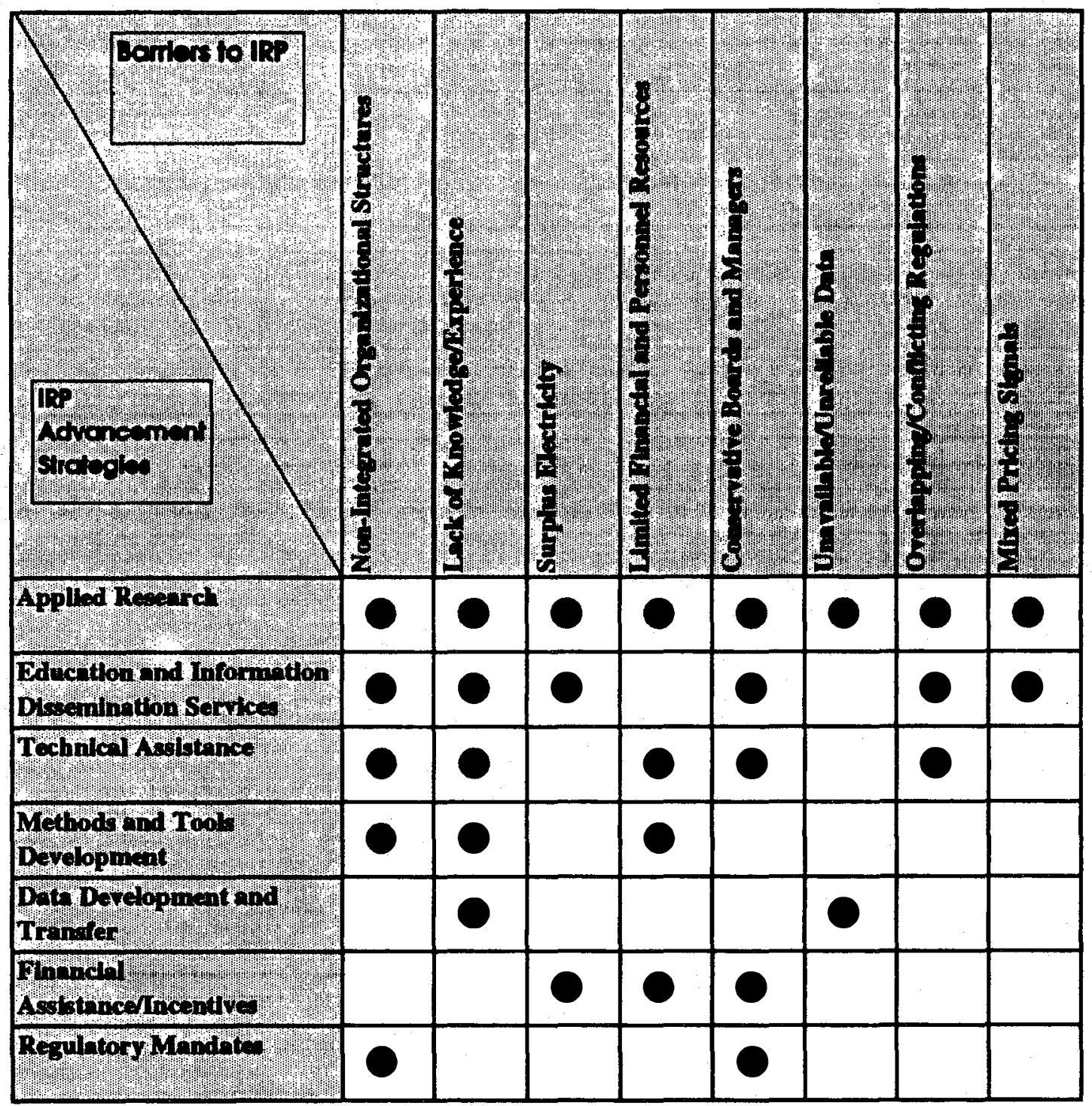

Note: Dot indicates the strategy that applies to the appropriate barrier.

Figure S-2. Applicability of IRP advancement strategies to overcome barriers to IRP implementation 


\section{Contents}

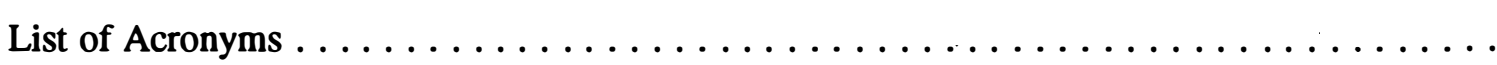

Introduction

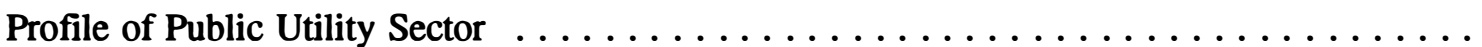

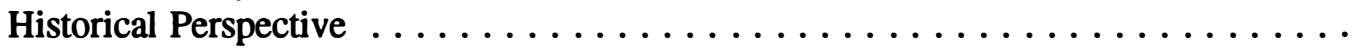

Organization

Key Attributes

Current Statistics

$\underline{\text { Page }}$

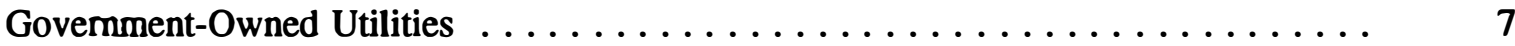

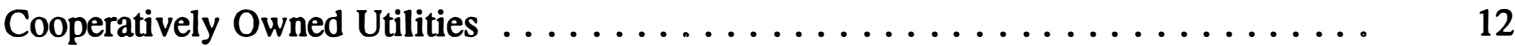

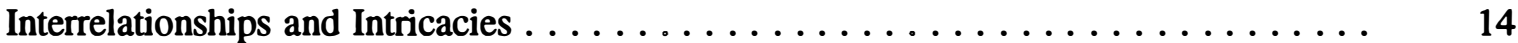

IRP in the Public Utility Sector $\ldots \ldots \ldots \ldots \ldots \ldots \ldots \ldots \ldots \ldots \ldots \ldots \ldots \ldots$

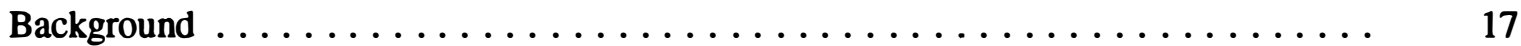

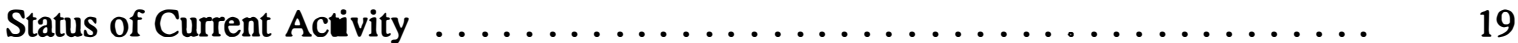

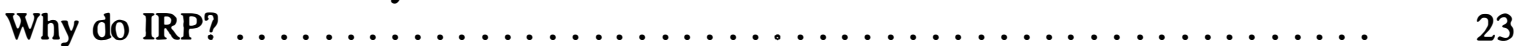

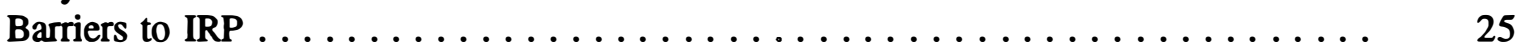

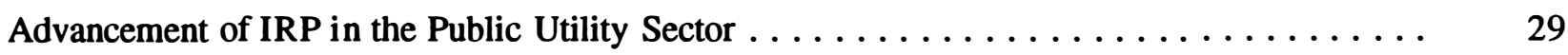

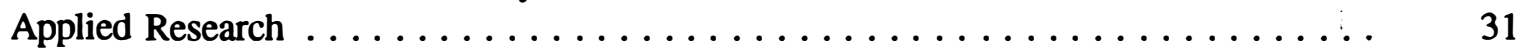

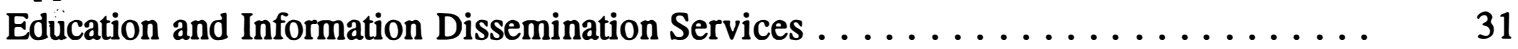

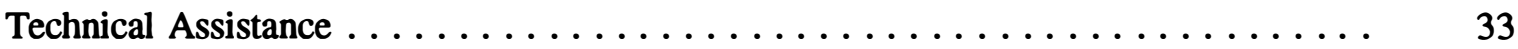

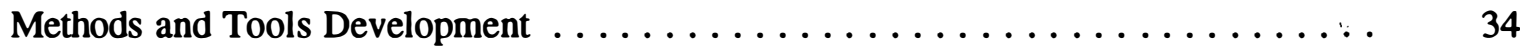

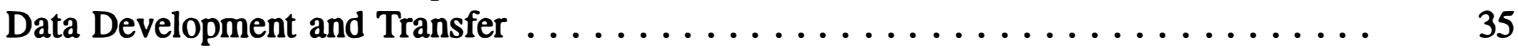

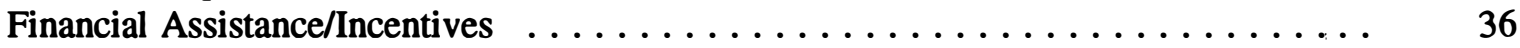

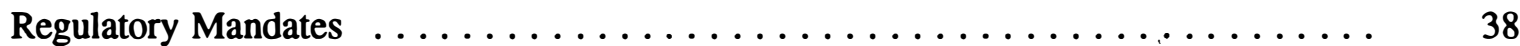

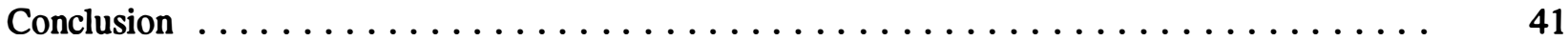

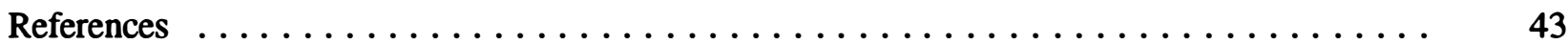

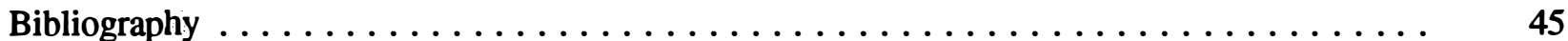

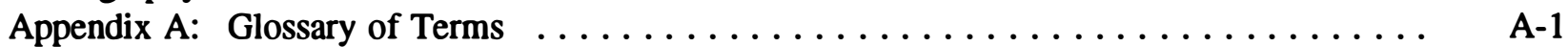

Appendix B: State Regulation of Public Utilities . . . . . . . . . . . . . . . . B-1

Appendix C: Representative Sample of Public Utilities: Selection Criteria and

Data Base ............................ C

Appendix D: IRP Telephone Interview Instrument $\ldots \ldots \ldots \ldots \ldots \ldots \ldots \ldots \ldots \ldots \ldots \ldots$

Appendix E: Public Utilities that Prepare IRPs $\ldots \ldots \ldots \ldots \ldots \ldots \ldots \ldots \ldots \ldots \ldots$ E-1 


\section{List of Figures}

$\underline{\text { Page }}$

S-1. Organization of U.S. electric utilities $\ldots \ldots \ldots \ldots \ldots \ldots \ldots \ldots \ldots \ldots \ldots$

S-2. Applicability of IRP advancement strategies to overcome barriers to IRP implementation $\ldots \ldots \ldots \ldots \ldots \ldots \ldots \ldots \ldots \ldots \ldots \ldots \ldots \ldots \ldots \ldots \ldots \ldots \ldots \ldots$ viii

1. Organization of U.S. electric utilities $\ldots \ldots \ldots \ldots \ldots \ldots \ldots \ldots \ldots \ldots \ldots \ldots$

2. Sample diagram of power transfers among public utilities $\ldots \ldots \ldots \ldots \ldots \ldots \ldots \ldots$

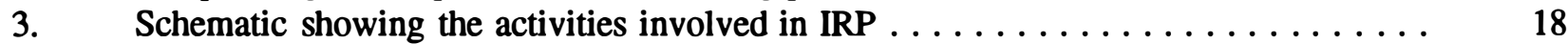

4. Percent of interview participants practicing IRP elements $\ldots \ldots \ldots \ldots \ldots \ldots \ldots \ldots 22$

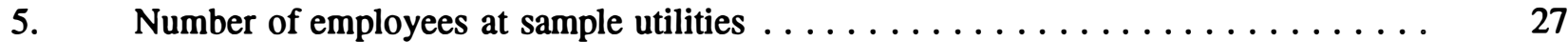

6. Applicability of IRP advancement strategies to overcome barriers to

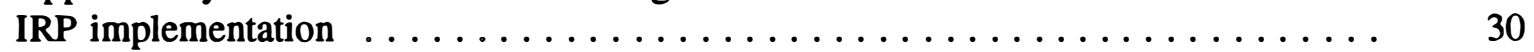

\section{List of Tables}

Page

1. Key Dates in the History of Public Utilities $\ldots \ldots \ldots \ldots \ldots \ldots \ldots \ldots \ldots$

2. 1990 Electric Utility Statistics $\ldots \ldots \ldots \ldots \ldots \ldots \ldots \ldots \ldots \ldots \ldots \ldots \ldots \ldots$

3. Number of Government-Owned Utilities by Subcategory $\ldots \ldots \ldots \ldots \ldots \ldots \ldots \ldots$

4. Number of Cooperatively Owned Utilities by Subcategory $\ldots \ldots \ldots \ldots \ldots \ldots \ldots \ldots$

B-1. State Regulation of Public Utilities . . . . . . . . . . . . . . . . . B-1

C-1. Profile Data Base for Representative Sample of Public Utilities . . . . . . . . . C-2

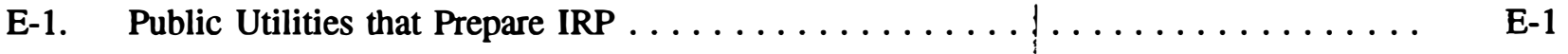




\section{List of Acronyms}

Acronym

APA

APPA

BPA

CFC

DSM

IOU

IRP

NRECA

PUC

REA

SEPA

SWPA

TVA

WAPA

\section{Description}

Alaska Power Administration

American Public Power Association

Bonneville Power Administration

National Rural Utilities Cooperative Financing Corporation

Demand-Side Management

Investor-Owned Utility

Integrated Resource Planning

National Rural Electric Cooperative Association

Public Utility Commission

Rural Electrification Administration

Southeastern Power Administration

Southwestern Power Administration

Tennessee Valley Authority

Western Area Power Administration 


\section{Introduction}

Integrated resource planning (IRP) is an approach to utility resource planning that integrates the evaluation of both supply- and demand-side options for providing energy services at the least cost. IRP provides a planning approach that is more adaptable than are traditional methods to fundamental changes impacting electric utilities. Many utilities across the nation practice IRP, and considerable study has been applied to this subject by such groups as the Electric Power Research Institute, Oak Ridge National Laboratory, Lawrence Berkeley Laboratory, and others. However, this IRP activity and research has been focused almost exclusively on investor-owned utilities (IOUs).

Public utilities ${ }^{1}$ account for almost $25 \%$ of U.S. electricity sales. However, very little emphasis has been placed on the IRP-related activities and needs of these utilities. The purpose of this study is to articulate what public utilities need to understand and implement IRP principles and practices, as well as to identify channels to effect greater consideration of IRP in public utility planning. Because the scope of this study is limited, it focuses on establishing a solid foundation from which to further develop IRP strategies for public utilities.

This report includes three major sections: a profile of the public utility sector, an IRP assessment for this sector, and the development of strategies for the advancement of IRP principles in this sector. The profile section of this report summarizes IRP-related characteristics of the public utility sector and emphasizes the unique and diverse aspects of this utility sector in comparison to IOUs. The profile addresses such topics as the sector's organization and key atributes, relevant public utility and comparative IOU statistics and the key characteristics of and interrelationships among the various types of public utilities.

The IRP assessment section establishes the current state of IRP activity among public utilities, and also identifies drivers and barriers related to IRP implementation. This assessment reflects the authors' existing knowledge base on IRP in the public utility sector, supplemented by contacts with relevant national public utility-oriented organizations and representative public utilities. The section on the advancement of IRP in the public utility sector focuses on building greater awareness, understanding, and implementation of IRP principles and practices. It builds on the preceding sections to delineate a number of strategies for advancing IRP in the public utility sector. The final section of this report presents the conclusions resulting from this work. A glossary of terms is provided in Appendix A.

\footnotetext{
${ }^{1}$ As defined for this study, public utilities refer to not-for-profit utilities that include federal, state, municipal, and cooperative utilities. Refer to the section entitled Profile of the Public Utility Sector and Appendix A: Glossary of Terms for additional definitions and discussions on public utilities.
} 



\section{Profile of the Public Utility Sector}

In many people's minds, electric utilities mean IOUs. In fact, public utilities existed before IOUs and currently sell $25 \%$ of the nation's electricity. The unique and diverse IRP-related characteristics of public utilities are articulated in this section because an understanding of these characteristics is essential to determine the IRP needs of the public utility sector.

\section{Historical Perspective}

\section{Public power was born of a desire by local citizens to provide for themselves-a desire to control, close to home, an essential service. \\ American Public Power Association}

Electric power made its U.S. debut in 1878 when a Cleveland, Ohio, inventor by the name of Charles Brush perfected the arc lamp and became the first American to devise practical street lighting. The nation's first public utility system was established in 1880 when Wabash, Indiana, used four of Brush's arc lamps to light their courthouse dome (See Table 1) (APPA History n.d.). Two years later, in 1882, Thomas Edison first delivered electricity from a central generator in New York City, opening the door for the electrification of America. During the 1880 s and 1890 s, public utility systems multiplied at a rapid pace, as did IOUs. By 1900, there were some 800 municipal electric utilities and about 2200 IOUs (APPA History n.d.). In these early years, the largest concentrations of public utilities were located in the Great Lakes states and the central part of the nation. They were predominantly small communities that could not obtain electric service from IOUs.

During the first decade of the 20th century, a major new player - the federal government-emerged to help fashion the future of public utilities. President Theodore Roosevelt (1901-1909) established the Reclamation Act of 1906, which specified that municipally owned utilities be given first purchase rights to surplus hydropower from federal irrigation projects (APPA History n.d.). This "preference" clause was first implemented in 1909 when the Bureau of Reclamation's first hydroelectric dam and power plant began operation on the Salt River. This power was purchased by the publicly owned Salt River Project and distributed to residents of the city of Phoenix, and also was used to irrigate the surrounding desert. The preference principle recognizes the people's right to benefit as directly as possible from a vital national resource - the nation's waterways and the power they produce as a by-product of multipurpose water projects that provide irrigation, municipal and industrial water, flood control, navigation, and/or recreation benefits (NRECA 1985).

As municipal and IOU systems continued to grow and serve urban areas of the country, most rural areas were without electricity. In 1929, for example, less than $10 \%$ of farms in the United States received electric service (NRECA 1990). Because rural customers were spread out over much greater distances than urban customers, the price of electricity paid by these few rural customers was usually at least twice that paid by urban customers and service was often erratic. Because of these inequities, efforts began as early as 1923 to find ways to bring electricity to rural America. In that year, the National Electric Light Association organized a committee to determine whether a profitable rural market for electricity existed. Findings from their studies indicated that electricity could significantly increase agricultural production, reduce operating costs, and improve rural life. In 1931, Franklin Roosevelt established the New York Power Authority, which demonstrated the practicality of providing electric service to rural consumers and has been said to have opened the door for the Rural Electrification Administration (REA).

The Tennessee Valley Authority (TVA) was established in 1933 as a corporate agency of the federal government and was charged with broad resource development in the Tennessee River Valley. The Tennessee Valley Authority Act (1933) authorized the TVA Board to construct transmission lines to serve 


\section{Table 1. Key Dates in the History of Public Utilities}

1880 - Nation's first public electric utility was formed (Wabash, Indiana).

1906 - Reclamation Act of 1906 established the original comerstone of "public preference" for federal hydroelectric power.

1909 - First federal hydroelectric dam, Salt River power plant, began operation.

1923 - Committee on Relation of Electricity to Agriculture (CREA) was formed to determine whether a profitable rural market for electricity exists.

1931 - New York Power Authority was established.

1933 - The Tennessee Valley Authority Act was passed and became the first official action of the federal government to bring electricity to rural America; TVA was established.

1934 - The first rural electric cooperative in the TVA area was established (Alcom County, Mississippi); "National Plan for the Advancement of Rural Electrification" memorandum was submitted-leading directly to the creation of REA.

1935 - REA was established to provide low-cost loans for the construction of generation, transmission, and distribution systems to serve rural areas.

1936 - First REA-fmanced rural electric cooperative line was energized in Mississippi; first generation and transmission loans were made in Iowa.

1937 - Congress created the Bonneville Power Administration to market hydropower from the Bonneville Dam.

1940 - The American Public Power Association was formed to represent the economic and political interests of the nation's locally owned utilities.

1942 - The National Rural Electric Cooperative Association was founded as a national service organization to support rural electric cooperatives.

1943 - The Southwestem Power Administration was established to market federal power in the southwestem states.

1950 - The Southeastem Power Administration was created to market federal power in 10 southeastem states; groups of municipal electric utilities began establishing joint-action agencies.

1967 - The Alaska Power Administration was established to carry out water and power planning, and power operations, in Alaska.

1969 - The National Rural Utilities Cooperative Financing Corporation was incorporated as an additional funding source for cooperatives.

1977 - The Westem Area Power Administration was created to market federal power in 15 westem states.

"farms and small villages" and to give "preference in the sale of surplus power to cooperative organizations of citizens or farmers" (NRECA 1990a). In 1935, REA was created to provide low-cost loans to cooperatives of farmers and businessmen for the construction of generation, transmission, and 
distribution systems to serve rural areas. The first REA-financed rural electric cooperative line was energized in Mississippi in 1936.

In 1937, Congress created the Bonneville Power Administration (BPA) to market hydropower from the Bonneville Dam. After Bonneville came the Southwestern Power Administration (SWPA) in 1943, the Southeastern Power Administration (SEPA) in 1950, the Alaska Power Administration (APA) in 1967, and the Western Area Power Administration (WAPA) in 1977. These five federal power marketing agencies, combined with TVA, provided public utilities in all parts of the country, except the Great Lakes region and New England, with access to federal hydropower.

The expansion of the public electric utility sector also led to the formation of the American Public Power Association (APPA) and the National Rural Electric Cooperative Association (NRECA). These two service organizations were founded in the 1940 s to represent the national interests of public utilities. In the 1950s, municipally owned electric utilities began establishing joint-action agencies to capitalize on the greater efficiency of large-scale generation and transmission. These agencies were created to fulfill a similar function as generation and transmission (G\&T) cooperatives, which have been major players in bringing power to rural America since the establishment of REA. In 1969, the nation's rural electric cooperatives organized the National Rural Utilities Cooperative Finance Corporation (CFC) to provide supplemental financing for rural electrification from private nongovernment sources.

The 1970s and 1980s were challenging times for the nation's electric utilities. During this period, many IOUs experienced electricity surpluses, rising costs, and pressure for consolidation and merger. Many public utilities faced these same challenges, as well as unique challenges of their own-such as declining rural populations. In the 1990 s, public utilities will be affected by significant changes occurring throughout the electric utility industry.

\section{Organization}

Figure 1 highlights the organization of the public utility sector. As shown in the figure, the public utility sector consists of "government-owned" utilities and "cooperatively owned" utilities. Government-owned utilities include all systems owned by federal, state, or local governments. As indicated, government-owned utilities can be broken into five major subcategories: federal, state, municipal, joint action agency, and other (e.g., public utility districts and irrigation districts). Cooperatively owned utilities are rural electric cooperatives and include both G\&T cooperatives and distribution cooperatives.

A more detailed discussion of government-owned and cooperatively owned utilities is provided in subsequent sections of this report. Where overlaps exist between these two major categories of public utilities, the categorization used in this study reflects that adopted by APPA (i.e., APPA 1992).

\section{Key Attributes}

The public utility sector is very diverse compared with the IOU sector. Several attributes distinguish all public utilities from IOUs: the lack of a profit motive; ownership and/or control by their consumers; and preference access to federal hydroelectricity.

Public utilities are not-for-profit entities, so they are not motivated by shareholder profits or rate-basing investments. Thus, any revenues received over and above operating expenses and debt service flow back to the consumers in the form of lower rates (and/or capital credits), improved service, and other community contributions. 


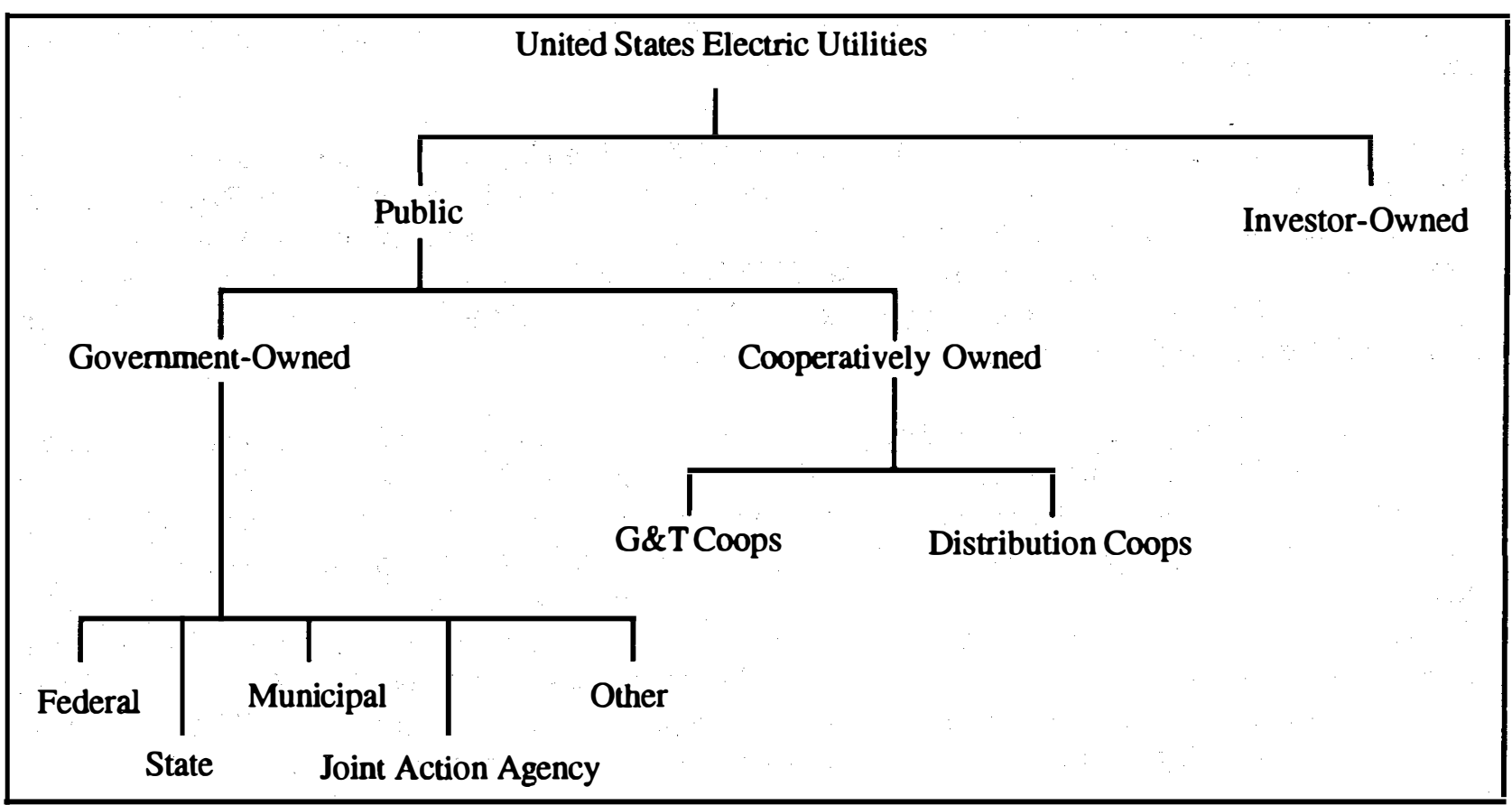

Figure 1. Organization of U.S. electric utilities

Public utilities are also owned and/or controlled by the people they serve. Investor-owned utilities, by contrast, are owned and controlled by stockholders who may or may not live in the service territory of the company. Public utilities are governed by their consumers through locally elected or appointed officials, such as city councils or boards of directors. Because they are governed by their consumers, public utilities are often considered to be self-regulating. As a result, most public utilities do not fall under the jurisdiction of the Federal Energy Regulatory Commission (FERC) (NRECA 1990b), and many are not regulated by state public utility commissions (PUCs). The degree of regulation varies from state to state-from no regulation to full regulation. Appendix B provides a listing of each state's regulatory jurisdiction over both government-owned and cooperatively owned utilities.

Public utilities also have greater access than do IOUs to low-cost hydroelectricity marketed by federal agencies as a result of the preference principal which specifies that public utilities be given first purchase rights to these power resources. First legislated in 1906, the preference clause has been included in more than 30 national statutes. Although the preference principal has often been challenged, it still remains important to the operation of many public utilities because it provides access to low-cost power.

Public utilities also have access to certain types of financing that are not available to IOUs. Government-owned utilities, for example, can issue tax-exempt bonds for capital expansion, which provide financing at a lower cost than taxable corporate bonds. And cooperatively owned utilities are eligible for REA loans that often carry lower interest rates than do private loans. 


\section{Current Statistics}

Table 2 presents key statistics for U.S. electric utilities. ${ }^{2}$ As indicated, there were a total of 3237 U.S. electric utilities in 1990; 62\% (2020) were government-owned systems, $29 \%$ (951) were cooperatively owned systems, and $8 \%$ (266) were IOUs.

Although IOUs accounted for only $8 \%$ of the nation's electric utility systems in 1990 , they provided more than $75 \%$ of the country's electrical energy. Government-owned utilities provided about $17 \%$ of total electric sales, and cooperatively owned utilities sold the remainder for combined sales of close to $25 \%$ of the nation's electricity. Electric revenues and the number of meters served by each utility grouping reflect a similar distribution.

These statistics clearly indicate that most of the country's 226 IOUs are very large companies, while the majority of the 2971 public utilities are considerably smaller systems. The average statistics in Table 2 illustrate the differences between the typical IOU and the typical public utility. The average IOU provides $7786 \mathrm{GWh}$ of electricity to over 300,000 meters. The average government-owned utility provides $225 \mathrm{GWh}$ of electricity to about 8000 meters, and the average cooperatively owned system sells $211 \mathrm{GWh}$ of electricity to some 12,000 meters. $^{3}$

\section{Government-Owned Utilities}

Currently more than 2000 electric utilities in the United States are owned by federal, state, and local governments. Approximately 35 million Americans, or 14\% of the nation's total population, receive electricity from these utilities (APPA Public Benefits n.d.). Table 3 categorizes these government-owned

Table 2. 1990 Electric Utility Statistics

\begin{tabular}{|c|c|c|c|c|c|c|c|}
\hline \multirow{2}{*}{$\begin{array}{c}\text { U.S. Electric } \\
\text { Utilities }\end{array}$} & \multirow[b]{2}{*}{ Number } & \multicolumn{2}{|c|}{ Electric Sales (GWh) } & \multicolumn{2}{|c|}{ Electric Revenues (\$) } & \multicolumn{2}{|c|}{ Electric Meters } \\
\hline & & Total & Avg. ${ }^{a}$ & Total & Avg. ${ }^{a}$ & Total & Avg. $^{a}$ \\
\hline \multicolumn{8}{|l|}{ Public } \\
\hline Gov't-owned & 2,020 & 454,908 & 225 & $25,810,741,000$ & $12,777,595$ & $16,347,403$ & 8,093 \\
\hline Coop-owned & 951 & 200,825 & 211 & $13,694,276,000$ & $14,399,870$ & $11,656,331$ & 12,257 \\
\hline IOUs & 266 & $2,071,069$ & 7,786 & $140,158,333,000$ & $526,911,026$ & $82,434,572$ & 309,904 \\
\hline Total & 3,237 & $2,726,802$ & - & $179,663,350,000$ & $55,503,043$ & $110,438,306$ & - \\
\hline
\end{tabular}

Source: American Public Power Association, Public Power Magazine: Annual Statistical Issue, January-February 1992.

Volume 50, No. 1, p. 56. Data reflect 1990 statistics based on Energy Information Administration Forms EIA-860 and EIA-861.

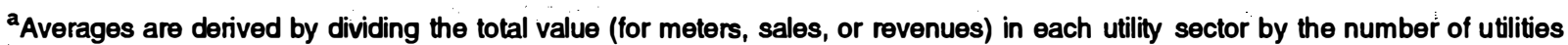
in that sector.

\footnotetext{
${ }^{2}$ The primary source for statistical data presented in the profile is the American Public Power Association's Public Power Magazine: Annual Statistical Issue for 1992. This magazine provides an authoritative source of compiled statistics for all not-for-profit and investor-owned utilities; these statistics are taken from Energy Information Administration (EIA) data. The budget for this study did not provide direct use of EIA data.

${ }^{3}$ The average electric sales values from Table 2 are inflated because wholesale and retail sales are double counted whenever a wholesale public utility (e.g., a transmission cooperative or a joint action agency) sells to a retail public utility such as a distribution cooperative or a municipality.
} 
Table 3. Number of Government-Owned Utilities by Subcategory

\begin{tabular}{lrc}
\hline Government-Owned Electric Utilities & Number & Percent \\
\hline Federal and State & 16 & 0.8 \\
Municipal $^{\mathrm{a}}$ & 1,814 & 89.8 \\
Joint Action Agency $^{2}$ & 54 & 2.7 \\
Other $^{\mathrm{a}}$ & 136 & 6.7 \\
$\quad$ Total & 2,020 & 100.0 \\
\hline
\end{tabular}

Source: American Public Power Association, Public Power Magazine: Annual Statistical Issue, January-February 1992. Volume 50, No. 1, p. 56. Data reflect 1990 statistics based on Energy Information Administration Forms EIA-860 and EIA-861.

${ }^{2}$ The number of utilities in the Municipal and Other subcategories is estimated, because the source document does not break out these subcategories, and no accounting is readily available.

utilities into federal and state systems, municipals, joint action agencies, and other public utilities. As illustrated, the 16 federal and state electric systems represent $1 \%$ of all government-owned utilities. The nation's 1800 municipal utilities account for about $90 \%$ of all government-owned systems (or more than $60 \%$ of all public utilities). Fifty-four joint action agencies constitute another $3 \%$ of this utility sector. Approximately 136 "other" government-owned utilities make up the remaining $7 \%$ of this utility sector, and include public utility districts, irrigation districts, territorial power authorities, and Indian power agencies. More detailed profiles of these various government-owned utilities are provided below.

The retail rates of govemment-owned utilities, on a national average, are lower than rates of IOUs. According to calculations based on U.S. Department of Energy statistics, the average residential customer of an IOU pays about $30 \%$ more for electricity than the average customer of a government-owned utility, while the average commercial/industrial customer of an IOU pays about $10 \%$ more. In addition, government-owned utilities pay proportionately more of their annual gross electric revenues to the communities in which they operate than do IOUs (APPA Public Benefits n.d.). Payments may be in the form of taxes, tax equivalent of in-lieu-of-tax payments, direct transfers to the general fund, or contributions of services.

The national interests of local government-owned utilities are represented by the American Public Power Association (APPA), a service organization located in Washington, D.C. APPA provides representation, training, counseling, and other services of public policy, engineering and operations, energy research, accounting and finance, human resources, customer service, and communications (APPA Public Benefits n.d.). APPA is funded by dues from members and revenues from services. Additionally, there are 39 statewide organizations located in 35 states that represent local government-owned utilities' interests and coordinate services on their behalf. These statewide organizations also are financed by dues and revenues, and they vary in size and resources.

\section{Federal and State}

The government-owned utility sector includes 10 federal power agencies and six state power authorities. Federal power agencies are U.S. government agencies that are involved in the generation, transmission, 
and/or distribution of electricity, and state power authorities are state-owned utilities that generate, transmit, and/or distribute electricity.

The 10 federal power agencies include ${ }^{4}$

- U.S. Army Corps of Engineers

- U.S. Bureau of Reclamation, Department of the Interior

- International Water and Boundary Commission

- Alaska Power Administration (APA)

- Bonneville Power Administration (BPA)

- Southeastern Power Administration (SEPA)

- Southwestern Power Administration (SWPA)

- Western Area Power Administration (WAPA)

- Tennessee Valley Authority (TVA)

- U.S. Bureau of Indian Affairs, Department of the Interior.

The U.S. Army Corps of Engineers, the U.S. Bureau of Reclamation, and the International Water and Boundary Commission are all federal agencies that operate hydroelectric facilities associated with federal water resource projects. The electric power generated at these federal water projects is sold at the wholesale level to all types of utilities, with preference by law given to public utilities. While some of the: hydropower generated at these projects is sold directly by these agencies (e.g., the Bureau of Reclamation sells power directly to some project use customers), the majority is marketed by the five power marketing agencies-APA, BPA, SEPA, SWPA, and WAPA.

APA carries out water and power planning, and power operations, in Alaska. APA serves three public utility customers, providing an average of about $7 \%$ of these utilities' total electrical requirements (Willis 1992).

BPA markets electric power and energy from federal hydroelectric projects in the Pacific Northwest. Currently, BPA allocates wholesale power directly to 120 public utilities. In 1991, BPA provided an average of $66 \%$ of these utilities' electrical needs (Lange 1992). Because BPA's charter requires it to meet the future electric needs of its customers, the agency is active in planning and developing future power facilities in the Northwest.

SEPA markets the surplus electric power and energy generated at reservoir projects operated by the Army Corps of Engineers in West Virginia, Virginia, North Carolina, South Carolina, Georgia, Florida, Alabama, Mississippi, Tennessee, and Kentucky (SEPA 1990). SEPA supplies an average of less than $15 \%$ of its 300 public utility customers' power requirements (Crenshaw 1992).

\footnotetext{
${ }^{4}$ These are the 10 federal agencies that file form EIA-861, which is a mandatory census used to collect information on power production and sales from electric utilities in the United States, its territories, and Puerto Rico.
} 
SWPA markets electric power and energy generated from federal projects in Kansas, Missouri, Oklahoma, Arkansas, Texas, and Louisiana. SWPA provides an average of $7 \%$ of the electricity requirements of its 90 customers (Hinshaw 1992a).

WAPA markets hydroelectric power from 51 federal hydroelectric plants to customers in 15 western states (WAPA 1992). Western also markets the U.S. entitlement from the coal-fired Navajo Generating Station in Arizona. Currently, WAPA serves approximately 400 public utilities ${ }^{5}$ (Council 1992). Although some of these utilities receive $100 \%$ of their requirements from WAPA, the agency supplies less than $50 \%$ of the electrical energy required by the majority of its customers (NEOS 1990).

TVA is a corporate agency within the U.S. government that has administrative flexibility in planning, construction, research and development, and programs of cooperation and education (NRECA 1990a). TVA's various construction and operation programs have been financed by congressional appropriations and by revenues from the sale of power and fertilizer. In 1959, Congress amended the TVA Act to authorize the sale of bonds and notes to finance the construction of power facilities. TVA currently provides $100 \%$ of the total electricity requirements for all 160 of its public utility customers (Maxwell 1992).

As part of the Department of Interior, the U.S. Bureau of Indian Affairs (BIA) is the lead agency charged with implementing congressional policy toward federally recognized tribes. There are several retail utility systems under the BIA, including the San Carlos Irrigation Project in Arizona and Mission Valley Power in Montana (APPA 1992).

The 10 federal power agencies allocate electrical resources to about 1100 public utilities. However, many additional utilities receive secondary benefits from the federal resources. For example, although SWPA has about 90 public utility customers who receive power allocations, these resources are actually used by more than 250 public utilities, which include both SWPA's wholesale utility customers and their member retail distribution systems (Hinshaw 1992b). The federal power agencies also sell power to each other. For example, SEPA allocates a portion of its resources to TVA, which reallocates these resources to its 160 public utility customers (SEPA 1990). And although the Bureau of Reclamation supplies a majority of the power marketed by WAPA, WAPA also sells power directly to Bureau of Reclamation facilities and to the U.S. Bureau of Indian Affairs (WAPA 1991).

In addition to the 10 federal power agencies discussed above, there are six state power authorities. These agencies are operated by their respective states, selling wholesale and retail power to utilities and industrial facilities, with preference given to public utilities. Four of the state power agencies were established in the 1930s: New York Power Authority (1931); South Carolina Public Service Authority (Santee Cooper-1934); Grand River Dam Authority, Oklahoma (1935); and the Lower Colorado River Authority, Texas (1935) (APPA History n.d.). These authorities were originally designed to provide jobs during the Depression and were charged with building hydroelectric facilities, improving navigation on rivers, and/or providing for flood and mosquito control. Two other state power agencies, the Arizona Power Authority and the Colorado River Commission, were formed in the 1940s to enable the sparsely populated states of Arizona and Nevada to receive and market their share of hydroelectric resources generated at Hoover Dam (NEOS 1992). These two agencies do not own generation or transmission facilities, but allocate federal resources to utilities and industrial facilities.

${ }^{5}$ In addition to these 400 public utilities, WAPA serves approximately 200 other customers, including IOUs and other federal agencies. 


\section{Municipal}

Municipal utilities are part of local government, like schools, parks, police, and fire protection. These utilities are governed locally and operated to provide an essential service at reasonable rates. Many are governed by elected officials, like a town council. Others are governed by a utility board whose members may be elected or appointed by a town council or mayor (APPA Public Benefits n.d.). In a few states, municipal utilities also are regulated by state PUCs.

Municipal electric utilities are located in every state except Hawaii and are characterized by an extremely wide variation in size. The largest municipal utility, the Los Angeles Department of Water and Power, provides electricity to 1.3 million meters, or nearly 4 million people. The smallest, in Radium, Kansas, serves 20 meters. Two-thirds of municipal utilities serve 3000 meters or fewer, and the average system serves 1750 meters $^{6}$ (Moline 1992a).

Municipal utilities may obtain their power supply in two different ways-self-generation and/or purchase from another supplier. Approximately $25 \%$ of municipals own generation plants (Moline 1992b), which use a range of resources including diesel, natural gas, coal, hydro, and geothermal resources. Some of these municipals generate $100 \%$ of their electrical requirements, while many generate only a portion. In fact, a number of municipal utilities own generation plants (e.g., diesel generators) but generate very little electricity - the plants are maintained as a backup, and less expensive electricity is purchased from another supplier. Municipal utilities purchase power from a range of sources, including joint action agencies, federal and state agencies, IOUs, and others (e.g., independent power producers and distribution cooperatives).

\section{Joint Action Agencies}

Joint action agencies are regional organizations formed by groups of utilities (typically by municipals) to jointly build or finance generation and transmission systems, contract for power supply, and share other services. These agencies make generating projects viable for small municipal utilities because they allow them to capture economies of scale and to enjoy the benefits of joint financing, pooled technical and managerial expertise, and increased leverage in contract negotiation (Puga 1992).

The legal organization of these agencies varies by state, while the services they provide vary according to their members' needs. Joint action agencies are typically owned and operated by the member utilities that establish the agencies. In 1990, there were 54 joint action agencies with a total membership of about 1100 utilities (APPA 1992). These member utilities are primarily municipals but also include some "other" government-owned utilities, as well as a few cooperatively owned utilities. Some joint action agencies are owned by as few as two or three members; others have memberships of 50 or more utilities. The membership of most of these agencies is confined to state boundaries; however, some serve members in multiple states.

By nature, the primary responsibility of these agencies is to supply power to member distribution systems. Some joint action agencies provide $100 \%$ of their members' electrical requirements, and others serve as supplemental suppliers. The power transmitted by joint action agencies comes from self-generation and/or purchases from other suppliers. Some agencies purchase all of the wholesale power (e.g., from federal power agencies, IOUs, and other public utilities) that they transmit, while others generate a significant portion of the supply. In addition to providing power supply services, many agencies provide other services, such as engineering, public relations, and legal support.

\footnotetext{
${ }^{6} \mathrm{~A}$ municipal meter serves an average of three people.
} 


\section{Other}

The other government-owned utilities in the United States include a mix of local and regional utilities. They include public utility districts, irrigation districts, Indian power authorities, and territorial power authorities.

Public utility districts are public political entities (similar to school districts) formed to provide power. Generally, they are governed by a board of directors elected on the state's general election ballot (NRECA 1992). Most of the more than 100 public utility districts are located in Washington, Oregon, Nebraska, and California (APPA History n.d.).

Irrigation districts (also known as electrical districts or water districts) are quasimunicipal utilities formed to serve primarily agricultural loads, particularly irrigation. The legal form of these utilities varies according to state laws. These districts are primarily located in the western United States, particularly in Arizona and California. Where agricultural lands have been developed for residential and commercial use (e.g., the Phoenix area and parts of Califomia), irrigation districts now serve predominantly nonagricultural loads.

In addition to public utility districts and irrigation districts, other government-owned utilities include Indian power agencies and territorial power authorities. Indian power authorities are electric utilities owned by Indian nations (e.g., the Navajo Tribal Utility Authority), and territorial power authorities are electric utilities owned by U.S. territories (e.g., the Guam Power Authority).

\section{Cooperatively Owned Utilities}

There are more than 950 rural electric cooperatives that provide electric service to 25 million Americans in 46 states, as well as Puerto Rico, the Virgin Islands, and American Samoa (NRECA 1991b). Rural electric cooperatives are consumer-owned entities established to provide electric service to rural America. These consumer cooperatives are incorporated under the laws of the state in which they operate.

The cooperatively owned utility sector consists of generation and transmission (G\&T) cooperatives and distribution cooperatives. As indicated in Table 4, there are more than $60 \mathrm{G} \& \mathrm{~T}$ cooperatives and close to 900 distribution cooperatives in the United States. The G\&T cooperatives provide all power supplies for their member distribution cooperatives, and these distribution systems provide the electricity to their members. In 1989, the nation's 62 G\&T cooperatives provided the power supply for 781 distribution cooperatives (NRECA 1991). The remaining 100 distribution cooperatives obtained power supplies from other sources (e.g., federal agencies, IOUs, and self-generation) (Olivier 1992).

Historically, rural electric cooperatives were financed by direct loans provided by the U.S. government through the REA at 2\% interest. This direct loan program was terminated in 1973 and replaced by an insured and guaranteed loan program that moved the rural electric cooperatives to a financing program

Table 4. Number of Cooperatively Owned Utilities by Subcategory

\begin{tabular}{lcc}
\hline Cooperatively Owned Electric Utilities & Number & Percent \\
\hline Generation and Transmission Cooperatives & 62 & 7 \\
Distribution Cooperatives & 889 & 93 \\
$\quad$ Total & 951 & 100 \\
\hline
\end{tabular}


based almost entirely on private sources. REA makes insured loans that are sold directly in the private market or to the U.S. Treasury for resale to private borrowers. Guaranteed loans are made by the CFC or other legally organized lending agencies (e.g., the Banks for Cooperatives) and guaranteed by the REA (NRECA 1992). As a result of these changes in the REA financing program, the majority of funds loaned to rural electric cooperatives through REA have been at market rates of interest.

The National Rural Electric Cooperative Association (NRECA) represents the national interests of rural electric cooperatives. NRECA provides legislative services and programs in management training, insurance, public relations, and advertising. NRECA is financed by dues from members and revenues from services. Additionally, in 37 of the $\mathbf{4 6}$ states where rural electric cooperatives are located, there are statewide organizations that represent members' interests and coordinate services such as communications, training, purchasing, billing, and research (NRECA 1991b). These statewide organizations also are financed by dues and revenues, and they vary in size and resources.

The retail rates charged by most REA-financed rural electric cooperatives tend to be higher than those of neighboring IOUs. On January 1, 1988, 79\% of REA borrowers had rates higher than those of neighboring IOUs for residential services at $1000 \mathrm{~kW}$ usage per month (NRECA 1990a). These higher rates are a result of the extra costs involved in providing electric service to sparsely populated areas.

\section{G\&T Cooperatives}

Generation and transmission (G\&T) cooperatives are power suppliers owned by several individual distribution cooperatives. They are governed by boards of directors consisting of representatives from all member distribution cooperatives. In many states, G\&T cooperatives also are regulated by state PUCs. For example, G\&T cooperatives are typically regulated for plant siting, and some states regulate G\&T wholesale rates.

The nation's 62 G\&T cooperatives are responsible for supplying all of the power required by their 781 distribution cooperative members and do so by generating the power and/or procuring it contractually from public or private utilities. About $44 \%$ of the electricity supplied by the nation's G\&T cooperatives is produced by $\mathrm{G} \& \mathrm{~T}$-owned plants, another 33\% comes from federal power sources, and the remaining $23 \%$ is purchased from IOUs (NRECA 1990a). In 1988, U.S. G\&T cooperatives had a total capacity of more than 30,000 megawatts, including parial ownership in units owned by other utilities. Seventy-five percent of this G\&T-cooperative-owned plant capacity is coal-fired, $14 \%$ is oil- or gas-fired, $10 \%$ is nuclear, and less than $1 \%$ is hydro (NRECA 1991a).

A few of the nation's G\&Ts are referred to as "super G\&Ts" because they are owned by other G\&T cooperatives. The term "paper G\&T" is used to describe a number of organizations owned by the distribution systems that are legally empowered to generate and transmit but have not done so. Instead, they bargain for power for their distribution cooperative members (NRECA 1991a). Also, there are a few G\&T cooperatives that do not generate power but own and maintain transmission lines to carry wholesale power from cooperative and public power projects to member distribution cooperatives.

\section{Distribution Cooperatives}

Distribution cooperatives are rural electric cooperatives that deliver electricity to residential, agricultural, and other consumers who are generally located in rural areas. Distribution cooperatives are governed by boards of directors who are elected by their member-consumers. In some states, distribution cooperatives also are regulated by state PUCs. For example, retail rates of distribution cooperatives are subject to regulation in 17 states (NRECA 1990). However, in some of those states, regulation is only applicable 
to those cooperatives whose consumers have voted for state regulation as a result of concerns about local governance.

In 1990, 889 distribution cooperatives provided electric service in $83 \%$ of the counties in the United States. Most distribution cooperatives are member-owners of a G\&T cooperative and receive $100 \%$ of their electricity requirements from the cooperatives. The approximately 100 independent distribution cooperatives obtain their power supplies from federal power agencies (e.g., BPA and TVA), IOUs, self-generation, or other sources.

A typical distribution cooperative serves 8000 consumers, owns and maintains 2000 miles of distribution line, and has 35 employees (NRECA 1991). The dispersed nature of its territory is illustrated by the following statistics: IOUs and municipal utilities, which typically serve urban areas, have an average of 32 and 41 consumers per mile of line, respectively. But distribution cooperatives, which serve predominantly rural areas, have an average of five consumers per mile of line (NRECA 1991). As a result, distribution cooperatives own and maintain more than half of the electric distribution lines in the United States, yet they serve only about $10 \%$ of the population.

\section{Interrelationships and Intricacies}

The profile just presented provides an initial description of the public utility sector. However, this utility sector is diverse and complex, and many interrelationships and intricacies are not fully reflected in this profile. A good example of this complexity is the transfer of power among public utilities. Figure 2 displays a number of power transfers that actually occur in one area of the United States; however, the interrelationships have been significantly simplified to provide an illustrative example.

Figure 2 illustrates the various utility entities, their power transfer functions (e.g., generation, wholesale marketing, transmission, and/or distribution), and their interrelationships. The Bureau of Reclamation (BOR), a federal power agency, generates power that is marketed at wholesale by W.APA, another federal power agency. In addition, the BOR provides power at wholesale to an irrigation district (ID) for pump operation (an end-use). WAPA sells the BOR power to a range of public utilities, including a state power agency (SPA), a G\&T cooperative, and a municipality (MUNI). In addition, WAPA sells power to the Bureau of Indian Affairs (BIA), another federal power agency, for distribution by a retail BIA utility system. The SPA receives a significant allocation of federal resources from WAPA and resells these resources to various public utilities in its state, including the G\&T cooperative, MUNI, ID, and BIA. Thus, each of these public utilities purchases the BOR power from both WAPA and the SPA. In addition, the SPA sells a portion of the BOR power to an IOU, reflecting state law governing the allocation of these resources. The SPA also purchases thermally generated power from the IOU and MUNI for resale to its other public utility customers. The IOU also sells power to the ID and BIA. The G\&T cooperative wholesales the power purchased from WAPA and SPA, combined with its own generation resources, to its distribution cooperative member. In tum, the cooperative wholesales some of this power to the MUNI. Finally, electricity is distributed to retail customers by the MUNI, COOP, BIA, IOU, and ID.

The initial profile of the public utility sector provides a foundation for understanding the IRP-related needs of the nation's public utilities. However, the diversity and complexity of these interrelationships must be recognized in developing appropriate strategies for the advancement of IRP in the public utility sector. 


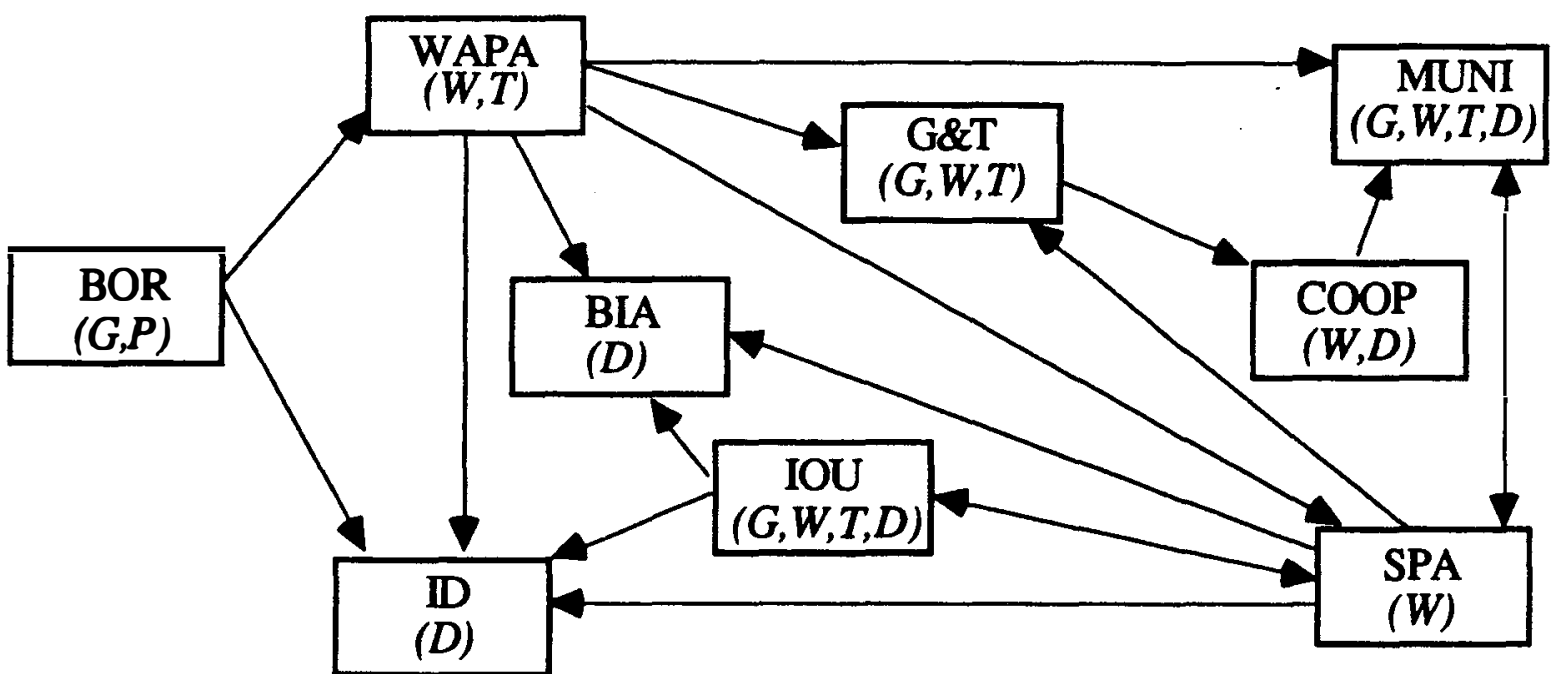

Utilities

BOR: Bureau of Reclamation

WAPA: Western Area Power Administration

ID: irrigation district

BIA: Bureau of Indian Affairs

IOU: investor-owned utility

G\&T: generation and transmission coop

MUNI: municipality

COOP: distribution coop

SPA: state power agency
(Areas of Utility Responsibility)

G: generation

P: project use wholesaling

W: wholesale marketing

$T$ : transmission

D: distribution

Figure 2. Sample diagram of power transfers among public utilities 



\section{IRP in the Public Utility Sector}

This section assesses the current state of IRP activity among public utilities, and identifies motivators and barriers related to implementing IRP in this utility sector. This assessment reflects both the authors' experience with IRP in the public utility sector and their contacts with national public utility-oriented organizations and representative public utilities. The national utility organizations contacted as part of this assessment include APPA, NRECA, REA, the five PMAs and TVA, the Northwest Power Planning Council, and the National Association of Regulatory Utility Commissioners. In addition, the authors contacted a limited sample of government-owned and cooperatively owned utilities, and conducted telephone interviews regarding IRP.

This assessment of IRP in the public utility sector includes four major subsections: a background discussion on IRP, a status report on current IRP activity by public utilities, identification of several drivers of public utility practice of IRP, and barriers to greater IRP implementation by public utilities. For each section, we combined generic information with interviews from the limited sample of public utilities. In several places, direct quotes from these discussions are provided.

\section{Background}

IRP is an approach to utility resource planning that integrates the evaluation of both supply- and demand-side options for providing energy services at the least cost. IRP differs from traditional utility planning in at least four ways:

- IRP explicitly includes energy efficiency and load management programs as energy and capacity resources.

- It considers environmental and social factors as well as direct economic costs.

- It involves public participation.

- It carefully analyzes the uncertainties and risks posed by different resource portfolios and by extemal factors (Goldman, Hirst, and Krause 1989).

IRP was first introduced in the late 1970 s to provide a more robust utility planning approach-one that is more flexible in adapting to external forces impacting electric utilities (EPRI 1987). These forces include increased competition, deregulation of electricity generation, greater access to utility transmission, and increased concern with the environmental consequences of producing and using electricity. In addition, there is considerable uncertainty about future load growth, fossil fuel prices and availability, and the costs and construction lead-times for various resources (Goldman, Hirst, and Krause 1989).

Figure 3 presents a schematic showing the various activities involved in IRP. The IRP process typically begins with a situation analysis, which includes identif ying goals for utility resource planning, developing alternative forecasts of future electric loads, assessing the costs and remaining lifetimes of existing resources, and identifying the need for additional energy and capacity resources consistent with the utility goals (Goldman, Hirst, and Krause 1989).

Next, alternatives that could satisfy the need for new resources are assessed. IRP involves a much broader array of resources than the central-station power plants traditionally planned for by utilities. These include supply, demand, transmission, distribution, and pricing alternatives. A comparative evaluation of all possible resource options is then conducted to identify the optimum mix of resources. Environmental and 


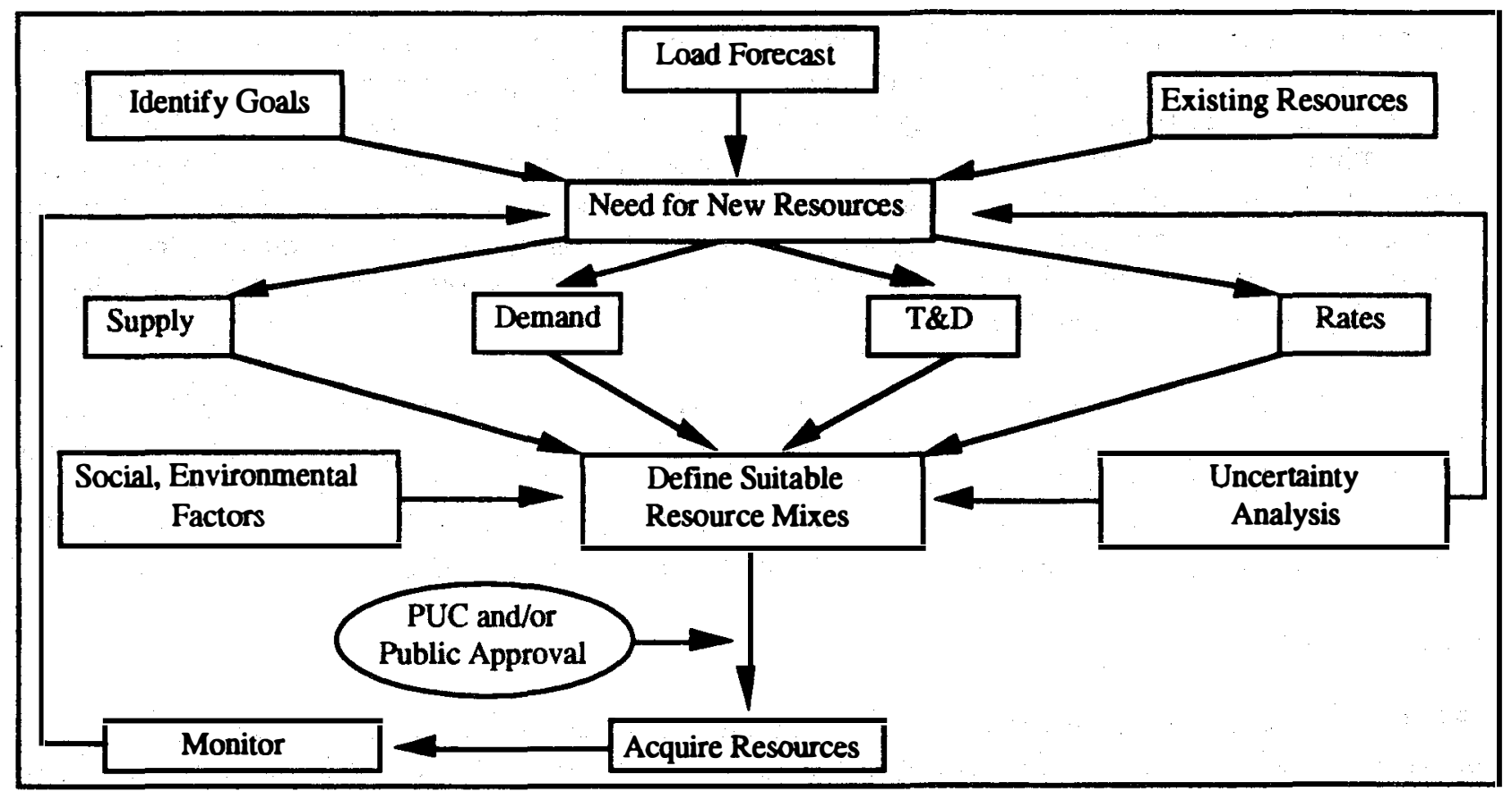

Source: Goldman, Hirst, and Krause 1989

Figure 3. Schematic showing the activities involved in IRP

social factors are also considered in this analysis as well as uncertainties posed by different resource portfolios and external factors.

Additionally, IRP is characterized by greater public involvement in the utility resource planning process. The public planning process helps to build consensus about the best resource plan and reduces public concerns about electric rates and utility management. After the plan is approved (by the PUC or other administrative or regulatory body for public utilities), it is implemented (i.e., resources are acquired). While the plan is in force, the utility monitors its implementation as well as external forces, and the plan may be modified as events and opportunities change over time.

Although Figure 3 represents an ideal IRP process, it is important to note that many IRPs include only a portion of these activities, depending on a utility's particular situation or the nature of a particular IRP requirement.

Many utilities across the nation practice IRP. However, the majority of IRP activity is a result of state PUC directives. Currently, at least 26 state PUCs require IRP by means of rules, legislation, or, in some cases, advanced nonregulated practice (EEI 1992). A number of other state PUCs are considering or developing IRP strategies. Because these IRP requirements only apply to those utilities regulated by the PUCs, IRP activity to date has focused on IOUs. However, some of these state regulations do impact public utilities. For example, the Wisconsin PUC requires detailed IRP for the state's public utilities, including the Wisconsin Public Power, Inc. System and its 30 municipal members, and the Dairyland Power Cooperative and its 28 member distribution cooperatives. 


\section{Status of Current Activity}

Although IRP has largely affected IOUs, it has also impacted public utilities. The most recognized example is the practice of IRP in the Pacific Northwest region served by BPA. BPA's charter requires it to meet the future electric needs of its customers. The Northwest Power Act of 1980 authorized the creation of the Northwest Power Planning Council (NWPPC), which was charged with developing a 20-year conservation and electric power plan for the region. The NWPPC, which is funded by BPA rates, develops integrated resource plans for the Pacific Northwest region and works with BPA, the region's utilities, and other agencies (e.g., PUCs) that implement the plans.

The NWPPC adopted its first IRP in 1983, with revisions following in 1986 and 1991. In each of these three plans, improved efficiency of electricity use was found to be the least expensive and most environmentally attractive resource alternative available to the region. Because the Pacific Northwest in the 1980s was in electricity surplus, the council's first two IRP action plans focused on "lost opportunity" resources, and developing the ability and infrastructure to acquire demand-side resources when additional capacity became necessary. The 1991 IRP was written as the regional power surplus was ending and the region was showing a need for new electric resources. As a result, the 1991 plan calls for the region to acquire about half of its new resource needs between now and the year 2000 from demand-side resources (about 1500 average MW of DSM savings are projected) (Morlan 1993). BPA and its customer utilities, and the region's six IOUs have developed acquisition plans and schedules designed to achieve the council's projected levels of conservation and efficiency.

In addition to the regional IRP planning conducted in the Pacific Northwest, several hundred public utilities currently practice IRP. In a recent survey conducted by APPA (Moline 1992), 27\% of responding government-owned utilities indicated that they prepare, or participate in preparing, an IRP that considers both supply-side and demand-side options for future resource decisions. Of the 227 utilities that reported IRP activity out of the sample of 851,89 prepare their IRP alone, and 138 prepare it with another organization such as a joint action agency or federal power agency. The activity reported in the APPA survey includes both formal and informal IRP. Because it is self-reported, activity that some of these utilities consider to be IRP may only be loosely defined as such. Although some of these government-owned utilities practice IRP in response to state PUC requirements, most do not have a regulatory mandate.

IRP also is practiced by cooperatively owned utilities. Some G\&T cooperatives prepare formal IRPs for their entire systems as do several independent distribution cooperatives. Based on a count of these G\&T cooperatives, their member distribution cooperatives, and those independent distribution cooperatives practicing IRP, more than 100 (or about $11 \%$ of all 951) cooperatively owned utilities currently practice IRP. The majority of these IRPs are required by state PUCs. ${ }^{7}$ Appendix E lists public utilities known to practice IRP. Although the percentage of IOUs practicing IRP has not been identified, it appears that significantly more IOUs practice IRP than do public utilities-particularly because about half of the states require IRP for IOUs.

Telephone interviews were conducted with a limited sample ${ }^{8}$ of government-owned and cooperatively owned utilities to gain additional insight into public utility IRP practices. Although the size of this

\footnotetext{
${ }^{7}$ Information presented in this study on cooperatively owned utility IRP activity reflects current knowledge of NEOS, NRECA, and REA personnel. Currently NRECA's IRP Task Force is surveying all G\&T cooperatives, including inquiring about the level of IRP activity and requirements for each organization (Oldak 1992).

${ }^{8}$ Thirty utilities were contacted, and 29 completed the study interview.
} 
sample is very small (i.e., 1\% of all public utilities) because of the limited scope of this study, the input received during the interviews provides a glimpse of public utilities' IRP activities and needs. The sample was chosen to reflect a cross section of public utilities, as profiled in the preceding section. Appendix C discusses the criteria used to select the sample. Additionally, the sample of selected public utilities includes an inflated percentage of public utilities that have conducted IRP, because input from these experienced utilities provides critical insights important to this study. Appendix $C$ also presents a data base of key utility and IRP characteristics for each of the selected utilities. Appendix D provides a copy of the questions asked of each of the sample utilities. These interview questions were discussed with utility general managers of small- and medium-sized utilities or with resource planning related departmental directors of large utilities.

Of the 29 utility interview participants, $11(38 \%)$ reported practicing IRP at their utility. This percentage is considerably higher than that for all public utilities because the survey sample was intentionally weighted toward utilities practicing IRP. The 11 interview participants who practice IRP summarized the outcome, or results, of their IRP activity. The most frequent responses included

- No results because IRP efforts are very recent

- An improved planning framework

- Developing and implementing DSM and other nontraditional resources

- Delaying the need for additional capacity

- Increased commitment to IRP and DSM (from board, management, and consumers) and increased staffing levels

- Reducing costs and avoiding capital investments

- Being a leader among public utilities.

However, what is considered to be IRP at one utility may not be considered IRP at another. Therefore, the telephone interviews on IRP activity focused on some key elements of IRP, which have more standard definitions than IRP itself. The seven IRP elements addressed were

- Load forecasting

- Supply-side resource evaluation

- Demand-side resource evaluation

- Consideration of environmental and/or social externalities

- Uncertainty (or risk) analysis

- Integrated resource evaluation

- Public involvement. 
Of the same 11 utilities, four practice all seven IRP elements. These four utilities include two municipalities, a joint action agency, and a G\&T cooperative. Two of these utilities are required by their state PUC to conduct IRP, and the other two conduct IRP on a voluntary basis.

The remaining seven utilities practice a majority of the seven IRP elements. However, each omits from one to three of the following: consideration of external factors, uncertainty analysis, and/or public involvement. These seven utilities include a diverse mix of public utilities, including municipalities, joint action agencies, distribution cooperatives, and G\&T cooperatives-and range in size from very small to very large. Although several of these utilities have PUC mandates for IRP, the majority do not.

Of the 18 sample utilities indicating that they do not conduct IRP, one actually practices all of the IRP elements and three practice a majority of the IRP elements. Several of these utilities practice the various IRP elements at a limited level, and others lack the integrated resource evaluation element. These four utilities include a G\&T cooperative, a joint action agency, a public utility district, and a distribution cooperative-all of which are relatively large systems.

The remaining 14 sample utilities practice three or less of the seven IRP elements: load forecasting, demand-side resource evaluation, and public involvement. These utilities are distribution systems (i.e., municipals, distribution cooperatives, and others) that currently receive $100 \%$ of their power from a wholesale supplier (i.e., joint action agency, G\&T cooperative, federal power agency, or IOU).

Figure 4 illustrates the frequency with which the sample utilities practice each of the seven elements (at least to some extent). As shown, load forecasting and demand-side activities are most common; uncertainty analysis, integrated resource evaluation, and consideration of externalities are least common. Figure 4 also shows that some of the utilities do not practice generally accepted utility functions such as load forecasting or supply-side evaluation. Several of these utilities are member distribution systems of joint action agencies or G\&T cooperatives that fulfill these functions on their behalf, while the others include independent distribution systems possessing existing long-term power supply contracts (e.g., with a federal power agency or IOU). Significant findings from discussions with the sample utility participants regarding each IRP element are summarized below.

\section{Load Forecasts}

Twenty-three of the sample utilities develop load forecasts, as indicated in Figure 4. Many of these utilities perform simple historical forecasts or projections; a few perform econometric and end-use forecasts. One participant mentioned that although his utility uses models for forecasting, there are some weak assumptions in the model (e.g., DSM impacts are presently not included). Another participant indicated that load forecasts are helpful for estimating DSM impact and persistence. For cooperatives, forecasting is performed in line with REA requirements, with the G\&T cooperative typically taking the lead.

\section{Demand-Side Resource Evaluation}

Twenty of the utilities evaluate DSM resources. Several of these utilities indicated that they evaluate 100 or more DSM alternatives, and many consider a wide range of options. One survey participant said, "We are counting "negawatts' in our resource portfolio," and another mentioned future plans for DSM bidding. With regard to assessing DSM, one utility uses the local IOU's DSM filings in its evaluation. Another mentioned the development of a DSM screening model and future plans for DSM bidding. Of the DSM activities currently in place, load management systems (e.g., direct load control and rates) are most prevalent. 


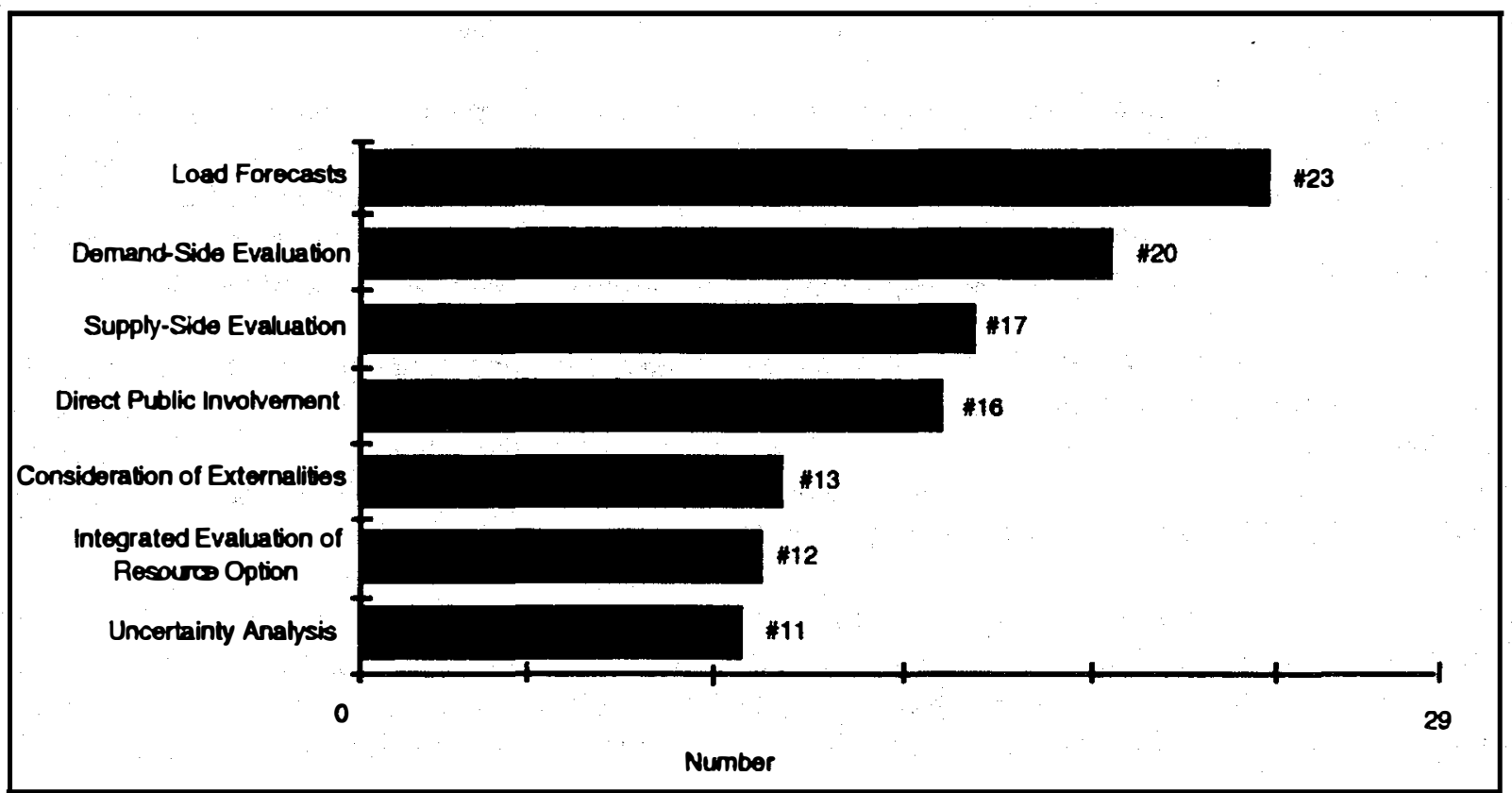

Figure 4. Number of interview participants practicing IRP elements

\section{Supply-Side Resource Evaluation}

Seventeen of the utilities contacted conduct evaluations of supply-side resources. Some of these utilities have looked at a limited range of supply-side resources (e.g., small peaking turbines), but many consider an extensive range of options including renewables, cogeneration, independent power producers, and traditional generation.

\section{Public Involvement}

More than half (16) of the utilities involve the public in resource planning activities. Many of these utilities emphasized that public involvement occurs through their elected boards or councils, which represent their consumers. From this perspective, it could be said that all public utilities inherently involve their public. However, a number of utility participants highlighted additional public involvement activities, such as public meetings and hearings, citizens' committees and advisory groups, and letters, to communicate with the public on various issues. These public involvement activities are more commonly conducted for demand-side activities than for all resource planning functions.

\section{Consideration of Externalities}

Less than half (13) of the utilities contacted consider external factors in their resource planning process. One of these utilities considers more than $\mathbf{3 0}$ different environmental and social factors; most focus on environmental factors related to generation (e.g., issues related to relicensing or expanding hydro resources) and DSM. Methods used to consider externalities include qualitative (e.g., "informal," "judgment calls," and "weighting"), percentage adder (e.g., "made assumption to increase DSM value by 10\%"), and direct quantification (e.g., "monetary method with avoided control-cost"). REA-required environmental reviews were mentioned by several cooperatives as their means of considering externalities. 
It is also important to note that several of the interview participants indicated that they are not familiar with the concept of "environmental and social externalities," and several others do not consider them because of the complexity and lack of data to quantify them.

\section{Integrated Resource Evaluation}

Twelve of the utilities perform an integrated evaluation of demand- and supply-side resources. One of the utilities stated, "This is tricky! [We] don't use a computer model, we do it the old-fashioned way-PC and calculator." This same agency indicated that its evaluation is based on economics, as well as intuition, and follows extensive prescreening. A number of other approaches were mentioned for evaluating supplyand demand-side resources; most emphasize economic and operating criteria to compare resource options. It should also be noted that several responses reflect confusion between resource evaluation and postprogram evaluation.

\section{Uncertainty Analysis}

This IRP element is both the least applied (only 11 of the contacted utilities) and the least understood of the seven elements. Several participants who indicated that their utility conducts uncertainty analysis were unclear about exactly how this is done (e.g., "I'm sure we do [uncertainty analysis], but [am] not sure what types of risks are considered"). One participant stated, "We look at certainty and uncertainty to determine how many load management devices to add to the system and which are most applicable based on our joint action agency situation." Uncertainties that are considered include variations in fuel/purchased power prices, changes in plant operations, and public perception issues. Methods for considering these uncertainties include load forecasting (e.g., range of loads), crude decision-tree analysis, scenario analysis, sensitivity analysis, and probabilistic analysis.

\section{Why do IRP?}

As discussed in the preceding section, a number of the nation's public utilities currently practice IRP for at least one of the following reasons:

- IRP is good fiscal business practice.

- IRP is required by federal and state agencies.

- IRP can address environmental considerations.

- IRP provides a sound planning methodology.

Foremost, public utilities practice IRP because it is good business. The fundamental goal of all electric utilities is to provide adequate and reliable electricity supplies to customers at the lowest possible cost. IRP can support this overall goal by ensuring the optimum resource mix and reducing uncertainties related to long-range planning. Other business objectives that IRP supports include enhancing customer services/relations and protecting the financial soundness of the utility. Because public utilities are nonprofit and consumer-owned, they have an inherent motive to practice prudent management. Some of the utilities contacted during this study believe that "public utilities owe it to their members to be conducting IRP on a voluntary basis"-to keep costs down, use resources efficiently, and best meet consumer needs. As one respondent put it, "Any utility worth its salt should already be doing IRP." Another stated, "The '90s will be the era of the survival of the fittest-if utilities don't do IRP, they will be left in the dust." The potential survival risks that this respondent may be referring to include bankruptcy, mergers/acquisitions, and utility sell outs by consumer owners. 
Regulations are another impetus for public utility IRP activity. Currently, at least six states require public utilities to conduct IRP. ${ }^{9}$ Wisconsin requires IRP for both government-owned and cooperatively owned utilities, and Vermont mandates IRP for government-owned utilities. In Alaska, Arizona, and Kentucky, regulators require cooperatively owned utilities to submit IRPs. Nebraska's public utilities prepare a periodic statewide plan for the Nebraska Power Review Board according to state statute. Other states are currently considering IRP requirements for public utilities. The REA considers Part 1710 of its final rule on "General and Pre-loan Policies and Procedures Common to Insured and Guaranteed Electric Loans" (REA 1992) to be an IRP requirement for the nation's cooperatively owned utilities. REA's rule requires two primary documents, power requirements studies and construction work plans, to be submitted on a routine basis. REA's requirements reflect various elements of the IRP process, with the greatest emphasis on load forecasting, DSM, and supply-side activities.

Several of the federal power agencies are also developing IRP requirements for their public utility customers. As previously discussed, IRP has been practiced on a regional basis in the Northwest by BPA and the NWPPC for more than a decade. As part of its new power marketing initiative, WAPA has proposed to require an IRP from each of its customers (WAPA 1992). This requirement could directly impact more than 400 public utilities, and several hundred others may be impacted indirectly. As proposed, purchasers of W APA power may submit plans individually or jointly with other purchasers who have common interests (e.g., power supplier and distribution members). SWPA recently developed an IRP clause for inclusion in all new or updated power contracts which states that ". . . the customer agrees to the extent practical to perform activities associated with IRP in securing future power resources . . ." (Martin 1992). However, SWPA's IRP contract clause will have limited short-term impacts because most purchasers have long-term contracts in place. Congressional legislation passed after this study was initiated (Energy Policy Act of 1992) requires WAPA customers to submit an IRP by November 1994. In addition, the legislation requires TVA to conduct an IRP program. It also states that utilities with 500 GWh or greater in retail sales must consider IRP.

Responses from the sample of utilities support the fact that regulations are one of the drivers behind public utility IRP activity. Five of the utilities contacted are currently required by state PUCs to practice IRP, and several others anticipate state requirements in the future. Several cooperatives mentioned the REA requirements; however, others seemed unaware of a current requirement. One cooperative official said, "The REA regulations are weak - basically we must submit a few load management and conservation programs. We want to make a transition from an REA workplan to a true IRP." Another participant stated that requirements are expected from WAPA; however, no one mentioned requirements (either existing or future) from other federal power agencies or from Congress.

Some sample utilities expressed opinions regarding the value of IRP regulations for public utilities. A few felt that IRP regulations have value, and provided comments such as the following:

- "IRP regulations would move, or force, conservative factions toward IRP, which will benefit our utility."

- "Regulation can be a positive way to encourage IRP if implemented appropriately (i.e., if regulators don't lose sight of the goal and have a perspective of reality)."

\footnotetext{
${ }^{9} \mathrm{~A}$ listing of state IRP requirements for public utilities currently does not exist. The information provided in this report is based on the authors' knowledge and discussions with key public utility personnel.
} 
For the most part, however, participants expressed both concern and opposition related to IRP regulations. The primary reasons for questioning the value of such mandates are summarized below.

- Regulation is contrary to the notion that public utilities are self-governed by their consumers. Public utilities want to maintain their local control.

- Regulation can easily get out of hand, become too stringent, and/or create unnecessary bureaucracy and paperwork. One participant stated, "regulation can hamstring action, prevent 'market-based" decisions, and add to costs."

- Regulations will not be effective in encouraging IRP because, as one participant stated, "If a utility is not motivated to do IRP on their [its] own, regulations will just create "empty motions "."

IRP is also practiced in response to an increasing concern with the environmental consequences of electricity production and use. As we enter the 1990s, the electric utility industry is being challenged to practice greater environmental stewardship. Public utilities have a direct responsibility to the "green" concerns of their citizens. IRP can help utilities meet environmental goals because it explicitly evaluates DSM and renewable energy options, which tend to be more environmentally benign than conventional supply-side resources, and also considers environmental externalities within resource evaluation. Several interview participants mentioned environmental concerns as a primary reason for practicing IRP. A "new board with an environmental agenda" was cited as the driver for one utility's IRP.

IRP provides a good long-range planning methodology, and some public utilities practice IRP for this reason. Planning is necessary to provide utilities with guidance on long-term directions and to help them prepare for uncertain future conditions. IRP has value to both IOU and public utilities because it provides a particularly effective planning framework. Several of the utilities contacted during this study emphasized that IRP provides a sound planning approach and a framework for decision making related to future resource requirements. Other participants emphasized its value in joint planning for power supply agencies and their member distribution systems.

\section{Barriers to IRP}

The preceding subsection discussed several drivers that have led to IRP activity by some public utilities. However, most of the nation's public utilities do not practice IRP. This study identified eight real or perceived barriers to greater IRP implementation in the public utility sector.

(1) Nonintegrated organizational structure

(2) Lack of knowledge and experience

(3) Surplus electricity resources

(4) Limited financial and personnel resources

(5) Conservative boards and management

(6) Unavailable or unreliable data

(7) Overlapping or conflicting regulation

(8) Mixed price signals. 
Many public utilities rely on other utilities for most or all of their power supplies. These utilities may be distribution cooperatives that are all-requirements customers of a G\&T, municipalities that depend on a joint action agency for resources and support, or independent distribution utilities that purchase power from a federal power agency, IOU, or other supplier. As a result, the generation and transmission functions of public utilities are often not integrated with the distribution function. This results in supply-side and demand-side "divisions" that are not part of the same utility.

Many of the utilities contacted during this study addressed whether IRP is applicable to nonintegrated public utility organizations, and they emphasized that IRP is most applicable at the power supplier level, with input and involvement from members or purchasers. One participant stated, "Small consumer-owned utilities . . . whose primary business is not the supply of power should be exempt from IRP regulations."

Lack of knowledge and experience with IRP is a significant barrier that has limited IRP implementation, including experience by public utility staff, management, governing bodies, and lack of understanding by public utility consumers. The extent of this barrier varies from utility to utility, with some systems having no familiarity with IRP and others lacking more specific IRP information (e.g., benefits, applications, and analysis methods). Because public utilities are considerably smaller than IOUs, they often lack staff with detailed expertise in areas such as IRP. This barrier is illustrated by the fact that almost $25 \%$ of all interview participants were not familiar with the term IRP. Those participants familiar with the term provided definitions for IRP which ranged from very general (e.g., "a review of options where you pick the most economic resources") to more specific definitions (e.g., "a means of evaluating all resources, including DSM and generation, and considering social costs to come up with a least-cost plan"). Several of the definitions reflected a lack of understanding, such as "to utilize resources other than power generation to serve demand." A number of interview participants indicated that a lack of IRP knowledge and experience has limited their activity in this area, and those participants currently practicing IRP highlighted the difficulties of communicating this complex process to boards and consumers-which inhibit its implementation.

Many utilities perceive that IRP is not necessary when significant surpluses of capacity and energy resources exist. This perception was substantiated by several of the sample utility participants. For example, several of these participants indicated that IRP is not relevant since their power supplier has surplus resources which will last for some time.

Public utilities, by virtue of size, have considerably less financial and personnel resources than do IOUs. Given the complexities of IRP, public utilities may be limited by their available resources. A number of the utilities contacted indicated that financial and manpower constraints are the largest barriers to implementing IRP. One participant stated, "A lot of public utilities don't have the funds available to conduct IRP or DSM." It is also significant to note that many public utilities do not have the same access to financing for nontraditional resources (e.g., DSM) as they do for supply-side resources. For example, REA does not currently provide long-term financing for DSM resources to cooperatively owned utilities, and government-owned utilities rarely seek bond financing for such resources.

Figure 5 indicates the number of employees at each of the sample utilities, which indicates the range and distribution of public utility staffing levels. As shown in the figure, the majority of the utilities contacted (20) have fewer than 100 employees, while others have more extensive staffs. When compared with the average IOU staff of about 2000 employees (EEI 1992), the manpower limitations of public utilities are quite evident. The largest sample utility has a DSM staff of about 150 persons, and one of the smallest utilities has a total of five employees who are responsible for all municipal public works, including electric, water, sewer, parks, fire, and streets. Even though resource constraints are clearly an issue for public utilities, it is significant that several survey participants who have conducted IRP emphasized that the benefits outweigh the time and expense involved. 


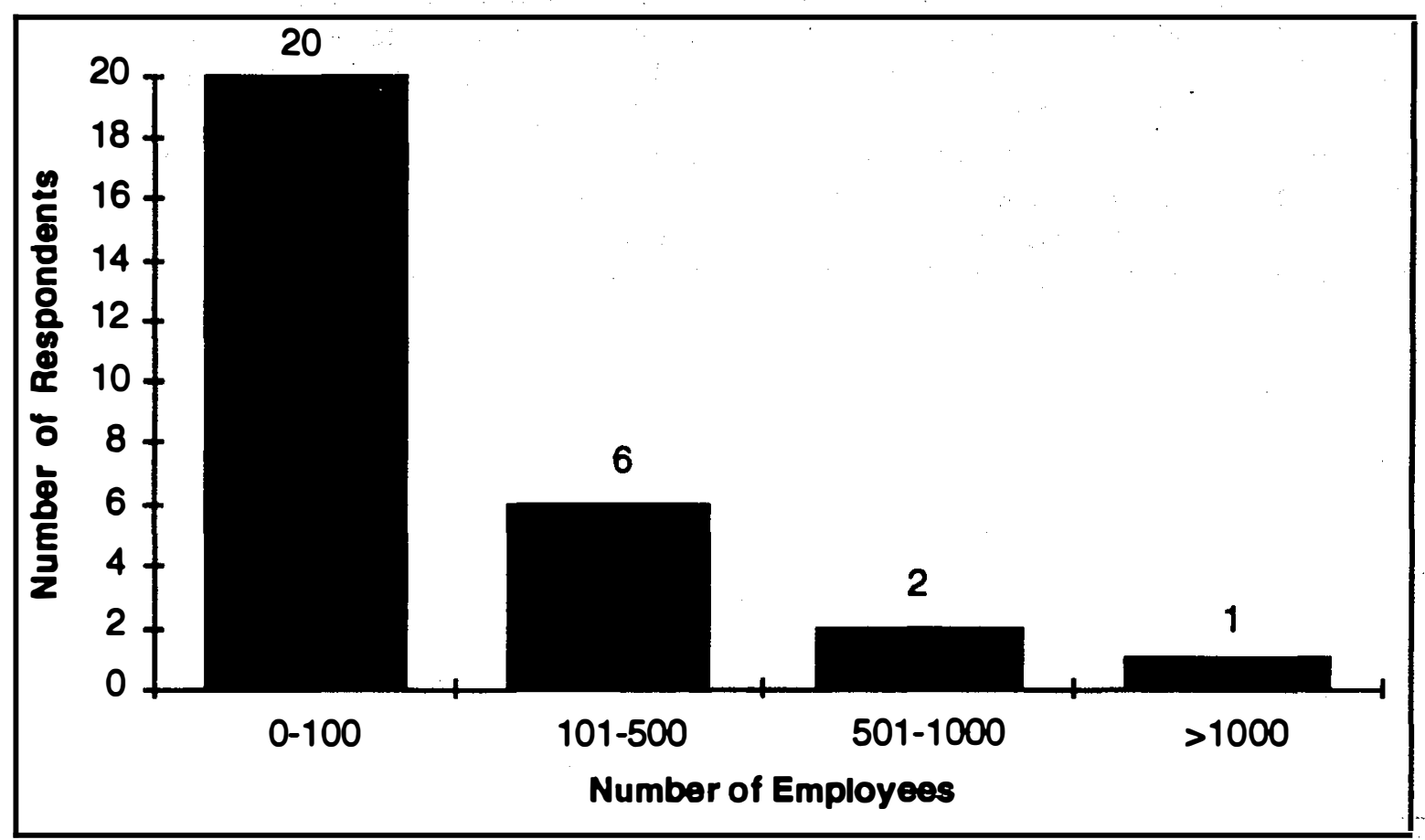

Figure 5. Number of employees at sample utilities

Traditional mindsets of some utility managers or governing bodies also limit IRP implementation. Because these key individuals establish the policies and priorities for the utility, their commitment to IRP is critical. However, many public utility managers are focused on operational issues and emphasize traditional supply-side approaches. Some of the utilities contacted during this study indicated that management and boards that lack foresight are a barrier. One stated, "Municipal utilities blame it [limited IRP activity] on 'being small, lack of staff, etc.," but the problem is really people's attitudes." Another participant said, "We need to change with the times . . . our council will have to move in this direction [IRP]."

IRP is an involved process that requires comprehensive and accurate data on a variety of energy and capacity resources. Current limitations to the availability of data on DSM resources and other nontraditional planning issues (e.g., externalities) present a barrier to IRP implementation for all electric utilities. However, this barrier may be more significant for public utilities that have less access to current research and data development. The lack of data results in greater uncertainties related to nontraditional resource options. As one survey participant said, "Since DSM programs don't have proven results, they are harder to sell."

Overlapping or conflicting regulatory requirements can also limit effective IRP. Because some public utilities face multiple IRP requirements (e.g., state, regional, or national), lack of a standardized framework sometimes results in mixed messages and increased administrative requirements. Although overlapping or conflicting requirements are currently a barrier for a number of public utilities, this barrier could become more significant in the future as additional IRP requirements are put in place. Several of the utilities contacted during this study voiced concerns about overlapping regulatory jurisdictions and the impact on their IRP activity. 
Mixed pricing signals can represent another barrier to greater IRP implementation. In particular, wholesale price signals that are not cost-based can send inappropriate price signals-preventing cost-effective resource planning decisions. Several of the sample utility participants highlighted the detrimental effect of wholesale rate structures that are not based on cost of service. This appears to be of most concern to distribution systems that are members of power supply agencies (i.e., joint action agencies or G\&T cooperatives). A separate barrier related to pricing signals results from low purchase power costs, which can discourage utilities from assessing other resource options. Several interview participants indicated that low purchase power costs limit the applicability of IRP for their utilities. 


\section{Advancement of IRP in the Public Utility Sector}

Considerable opportunity exists to advance IRP activity in the public utility sector. However, a number of barriers must be overcome before IRP is considered by the majority of the nation's public utilities. This section delineates a number of specific strategies for building greater awareness, understanding, and implementation of IRP principles and practices in the public utility sector. Summarized below are key points that guide the establishment of appropriate strategies and key participants who play a significant role in advancing public sector IRP.

- IRP advancement strategies must recognize the diversity of the public utility sector because a "one size fits all" concept does not apply to this sector.

- Unique attributes of public utilities (e.g., nonprofit and small size) must be addressed because many IRP advancement strategies that apply to IOUs are not directly transferable to the public utility sector.

- Regulatory authority over public utilities lies foremost with local governing bodies - thus these bodies represent a key point of influence for IRP advancement. Although many of these utilities are also subject to nonlocal regulation (e.g., state PUCs), the nature and scope of this regulation varies widely.

- For government-owned public utilities, $A P P A$ and statewide municipal associations are well positioned to provide IRP services and assistance. Additionally, over half of the utilities in this subsector can be reached by targeting IRP advancement strategies at the 64 joint action agencies and their member systems.

- For cooperatively owned public utilities, NRECA and statewide REC associations are key to providing IRP services and assistance. Additionally, $R E A$ is a major financial participant with these utilities. Close to $90 \%$ of the utilities in this subsector can be reached by targeting IRP advancement strategies at about $60 G \& T$ cooperatives and their member distribution cooperatives.

- DOE's federal power agencies have contractual and service relationships with more than $50 \%$ of all public utilities. These agencies can play an important role in the advancement of public utility IRP activity.

The following subsections present seven strategies for advancing IRP principles and practice in the public utility sector. These IRP strategies reflect the knowledge and experience of the authors and of NREL personnel, and are supplemented with input provided by interview participants. Based on the general nature of this study, strategies are presented that are applicable to the public utility sector as a whole. The discussion presented for each of these strategies more concisely addresses their application to the diverse public utility sectors. However, a more comprehensive development of these strategies will be required to advance IRP to the fullest practical extent.

Figure 6 lists the seven strategies and indicates the applicability of each strategy for overcoming the various barriers identified to greater IRP implementation. No single strategy is sufficient to fully advance IRP in the public utility sector-a combination of strategies is recommended to effectively overcome the various barriers. A number of organizations (e.g., APPA, NRECA, and WAPA) are currently implementing many aspects of the seven strategies. The strategies presented in this study are not intended to compete with, or reinvent, existing efforts by these organizations. Rather these strategies are directed at supporting and expanding current IRP-related services for public utilities. The fact that most of the nation's public utilities currently do not practice IRP is evidence that the resources that have been applied 
to advance IRP in this sector are insufficient. This study encourages a greater coordination of available resources to maximize benefits.

The seven IRP advancement strategies are presented in more detail below. When appropriate, IRP advancement mechanisms currently being applied by other organizations are cited as examples. Key participants for each strategy are delineated, including target recipients (i.e., those subgroups most likely to benefit from the strategy) and organizations positioned to deliver the strategy. Finally, the barriers that can be overcome by each strategy are discussed.

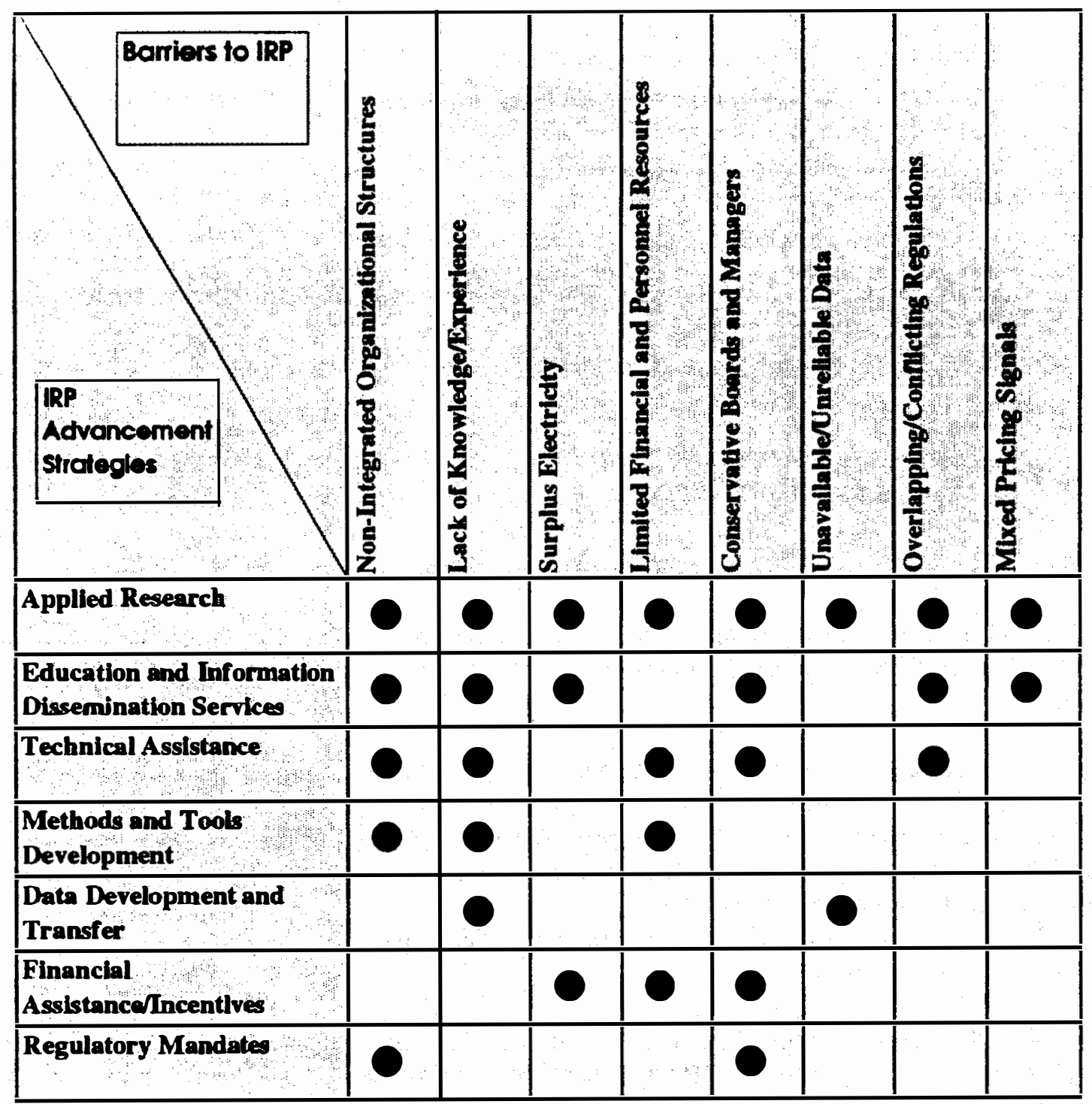

Note: Dot indicates the strategy that applies to the appropriate barrier.

Figure 6. Applicability of IRP advancement strategies to overcome barriers to IRP implementation 


\section{Applied Research}

Applied research is needed to further investigate IRP as it applies to public utilities. Because limited work has been done in this area to date, additional research is critical to developing and implementing appropriate IRP advancement strategies. This applied research should be conducted before, as well as concurrent with, the development of various other strategies and is necessary to enhance the effectiveness of these strategies.

\section{Research Mechanisms}

Many types of applied research should be pursued to advance IRP in the public utility sector. These include, but are not limited to the three points below.

- More detailed profiles: many aspects of public utilities are relevant to IRP, yet are not currently documented in a format that is readily usable for IRP-related activities. For example, computerized mapping of the complex interrelationships and power transfers among publics would be a valuable tool for IRP planning and support. Interest in a pilot GIS mapping project of this nature exists at NREL. Other attributes that should be profiled in more detail include electricity costs and pricing, financing issues (e.g., bonds and transfers to general funds), and state PUC activity (e.g., current and anticipated IRP regulation).

- Interviews with public utilities: the IRP interviews conducted during this study provided a limited perspective of the public utility sector. We recommend conducting additional interviews with an expanded sample of utilities to further articulate the IRP needs of public utilities.

- Evaluation of IRPs: examining IRPs developed by a cross section of public utilities (e.g., various types, sizes, and situations; and with and without regulatory mandates) would provide a better understanding of the application of IRP in the public sector. This activity should also include the testing of case studies for use in educational and technical assistance activities.

\section{Participants}

Applied research on IRP and the public utility sector would benefit all public utilities by ensuring that IRP is appropriately applied in this sector. Such research could be conducted directly by DOE through its staff or contractors. Any or all of the key participants highlighted above could direct applied research in this area as well. For example, the NRECA is currently conducting a survey to determine the status of current IRP activity and requirements for the nation's G\&T cooperatives.

\section{Barriers Addressed}

This IRP advancement strategy can be applied to all of the various barriers to greater IRP implementation. By providing better information about the IRP needs of public utilities, applied research can help overcome all of the barriers to IRP illustrated in Figure 6.

\section{Education and Information Dissemination Services}

Education and information dissemination result in greater awareness and understanding of IRP principles by public utilities. These services should be provided for a range of IRP topics, including background information (e.g., What is IRP? What are the benefits of IRP?), how-to information, and various special topics (e.g., IRP in overcapacity situations, joint IRPs, and rates and IRP). Interview participants cited education and informational services most frequently as a beneficial type of IRP assistance for public 
utilities. As one participant stated, "We'd be plowing new ground to get into IRP, so we would need a lot of information."

Education and information dissemination are also recommended for public utility audiences, such as regulators and federal agencies, which play a key role in IRP implementation by publics. For example, the availability of sound, accurate, and timely information for state, regional, and national regulators is necessary to ensure that IRP regulations impacting publics are appropriately designed and effectively implemented.

\section{Delivery Mechanisms}

A variety of mechanisms should be used to deliver educational and information dissemination services in the public utility sector. Some these mechanisms are discussed below.

- Publications are printed materials designed to communicate IRP information and can take many forms, including booklets and brochures, and should be developed for various audiences and topic areas. Although background publications on IRP can be readily used as stand-alone documents, many more detailed publications can also be used effectively as a complement to hands-on training.

- Audiovisual materials include videotapes and slide libraries that address IRP background information as well as more detailed IRP topics. Standardized audiovisuals can bridge the gap between publications and customized workshops or seminars. For example, an informative video on "IRP and the Public Utilities" is needed for state regulators and others who have jurisdictional authority over publics but may not be particularly familiar with this utility sector. WAPA is currently developing an IRP slide library that includes more than 100 slides on a range of IRP topics. The slides can be used by a public utility manager to make a presentation to the board or public, or by WAPA personnel during an IRP seminar.

- Workshops and seminars provide a forum for group training and information exchange. Small regional or local workshops are most effective for attracting management and staff of small- to medium-sized public utilities. Several interview participants emphasized the value of low-cost, local workshops using speakers who can relate to small utility IRP. National and/or regional IRP training seminars may be more effective for medium-to-large public utilities. Existing regional forums (e.g., statewide annual meetings) provide an opportunity to offer educational services to part-time governing board/council members who are often difficult to attract to workshops and seminars.

- Correspondence courses should be offered to public utilities as an alternative to attending workshops and seminars. Such courses are particularly relevant for how-to IRP topics (e.g., analyses of various resource options) that apply training information to utility-specific situations.

- Regulatory network is a formalized method of information exchange among the various agencies with regulatory authority over public utilities (e.g., U.S. Congress, federal power agencies, REA, and state PUCs) that would enhance coordination and cooperation, and minimize overlaps and conflicts. This regulatory network could take many forms, including a task force or network group, an electronic bulletin board service, or a newsletter. Recent collaboration among WAPA, the New Mexico PSC, and REA on multiple IRP regulation impacting New Mexico's rural electric cooperatives is an example of such coordination. However, a national network would offer significant benefits to public utilities and their regulators. 


\section{Participants}

IRP-related education and information services should be targeted at a number of audiences, including public utility staff, management, and governing directors; and public utility consumers. These services should also be offered to regulatory personnel and others (e.g., consultants), and should include general information on public utilities, as well as specific IRP information. The delivery of education and information services can be accomplished by all of the key public utility participants. Many of these key participants currently provide education and/or information services to their constituencies, including APPA, NRECA, REA, SEPA, SWPA, and WAPA; coordination among these entities is important.

\section{Barriers Addressed}

Education and information services can help address six of the barriers to IRP, as illustrated in Figure 6. Although this strategy applies most directly to the lack of knowledge or experience barrier, information and education can also address various other barriers as well. Additionally, the education and information dissemination strategy offers an opportunity to reinforce the positive drivers behind IRP activity (e.g., IRP is good business practice).

\section{Technical Assistance}

Technical assistance supplements public utility personnel resources by providing one or more "experts:" to guide and support IRP activities. This strategy provides more intensive assistance than education and information dissemination services. Because technical assistance can address any IRP topic, it is generally best applied to resource intensive aspects of IRP (e.g., analysis of resource options, and implementation of plan) or areas requiring specialized expertise (e.g., rates determination). Some interview participants indicated that professional assistance to supplement limited public utility staffs would be beneficial.

Technical assistance should also be provided to regulatory agencies to support efforts related to public utilities. This strategy can be employed to provide guidance to ensure that regulations impacting publics are appropriately designed and effectively implemented.

\section{Delivery Mechanisms}

A number of technical assistance mechanisms should be used to advance IRP in the public utility sector. These include

- Consultations: consist of one or more "experts" meeting with an individual utility or a small group of utilities to provide specific IRP assistance. These experts would include "peers" from other utilities, consultants, and/or others. A consultation, which would generally be limited to a one-day meeting, might include a discussion of the problem to be addressed, a transfer of the expert's relevant experience, and a brainstorning session to establish a process for the utility to further address their situation. APPA and WAPA have developed a similar "Peermatch" program for conservation and renewable energy activities, which could provide a model for an IRP consultation service.

- Direct support: involves providing more intensive assistance to support public utility IRP activity. This support would range from assisting a group of utilities to establish the framework required to conduct IRP to actually developing an IRP on behalf of one or more utilities. The direct support would involve longer-term (e.g., 3 months to 1 year or more) assistance to meet specific needs of public utilities. Several federal and regional agencies currently provide IRP-related direct support to public utilities, including REA, WAPA, and NWPPC. In addition, a few joint action agencies have employed innovative direct support mechanisms, including circuit riders, which extend the personnel resources 
of member distribution systems. Such a strategy could meet the need reflected by an interview participant who said, "Someone to just come in and do the IRP—utility just provides data."

- Demonstration projects or case studies: are a form of direct support, which should be applied selectively to demonstrate IRP applications for public utilities. IRP assistance should be provided to a cross section of public utilities (e.g., various sizes, types, and situations) and the results of these efforts demonstrated to other public utilities through education and information dissemination, consultations, etc.

- Regulatory assistance: involves technical support to regulatory agencies to ensure that regulations impacting publics are appropriately designed and effectively implemented. Regulatory assistance could range from the development of model regulations that recognize the diversity and uniqueness of public utilities, to pilot projects supporting one or more agencies (e.g., PUC and PMA) currently investigating or developing IRP regulations that will impact public utilities, to establishing collaborative IRP forums for public utilities. For example, the California Municipal Utilities Association conducted a municipal collaborative process on IRP and energy efficiency in concert with WAPA and the California Energy Commission.

\section{Participants}

IRP-related technical assistance should be targeted at small- to medium-sized public utilities with limited personnel and financial resources. In addition, this assistance should be targeted at utilities that are motivated to pursue IRP activity. Maximizing the transferability of technical assistance services (e.g., through demonstrations and pilots) can also ensure their value. The delivery of technical assistance services can be accomplished by the key public utility participants including national organizations such as APPA, NRECA, and REA as well as regional agencies like the federal power agencies, joint action agencies, and G\&T cooperatives. Statewide municipal and REC associations also can play an important role in the delivery of technical assistance services.

\section{Barriers Addressed}

Technical assistance can be applied to address five of the barriers to IRP, as illustrated in Figure 7. Although this strategy is most directly applicable to the limited financial and personnel resources barrier, technical assistance can be used to address four other IRP barriers as well. Additionally, technical assistance provides an opportunity to reinforce the positive drivers behind IRP activity (e.g., IRP is good business practice).

\section{Methods and Tools Development}

IRP methods and tools designed specifically for public utilities provide a realistic framework for the practice of this complex process. Existing IRP tools (e.g., software and handbooks) generally reflect the needs of large, investor-owned utilities and are not readily applicable to the majority of public utilities. A number of interview participants indicated that analysis tools and standard methods are needed for public utilities. These methods and tools can address the various analytical steps associated with IRP, including resource evaluation and integration, and can also be developed for other IRP topics such as resource bidding or rate design.

\section{Delivery Mechanisms}

Two mechanisms for delivering this strategy, publications and computer software, are discussed below. 
- Publications: the provision of detailed how-to information on IRP can be extremely valuable to public utility personnel, who often possess limited IRP education and experience. Types of publications which can provide IRP methods include guidebooks, workbooks, manuals, and books of standards. For example, WAPA and SWPA are currently codeveloping a "Resource Planning Guide," which consists of a number of workbooks tailored to various sizes of public utilities.

- Computer software: should be designed to provide public utilities with analysis tools that are appropriate for their energy situations and available personnel resources. One interview participant said, "[We need] a spreadsheet that we could plug information into and compare resource options, since a major engineering study is not realistic." Another stated that a "menu-driven PC program that we could fill in and run" would be beneficial.

\section{Participants}

IRP methods and tools development should be targeted at small- to medium-sized public utilities with limited resources and experience. The development of simple tools can be accomplished by any of the key public utility participants and may be most appropriate at the local and regional level. For example, joint action agencies or G\&T cooperatives could develop customized spreadsheets with accompanying documentation. However, the development of more detailed methods and tools, such as IRP manuals and computer models, require significant expertise and resources. Thus, these efforts can be accomplished through separate and/or collaborative efforts by national organizations such as DOE, APPA, and.NRECA.

\section{Barriers Addressed}

The methods and tools development strategy is directly applicable to three of the barriers to greater IRP implementation. This strategy would help to overcome the nonintegrated organizational structure barrier by providing tools and methods that lead to increased organizational integration. In addition, it addresses lack of knowledge/experience and limited financial and personnel resources barriers by providing boilerplates that streamline the IRP process.

\section{Data Development and Transfer}

This strategy provides public utilities with reliable data for use in IRP. It consists of data development, collection, and transfer amongst the nation's public utilities. A few of the interview participants suggested that improved IRP-related data are needed. One participant stated, "Data are critical-good sound data from real experiences . ..". The type of data that this strategy could make available to public utilities includes resource costs (e.g., $\$ / \mathrm{kW}$ for various demand-side and supply-side options), impacts (e.g., $\mathrm{kW}$ and $\mathrm{kW}$ savings associated with various demand-side options), and externality costs (e.g., range of direct environmental costs associated with various resources).

\section{Delivery Mechanism}

This strategy should be accomplished by the establishment of national and/or regional data banks. The data banks would represent a consolidated source of IRP-related data that are particularly relevant to public utilities. Although some data banks currently exist (e.g., NORDAX and CEED), these focus primarily on demand-side data and mostly apply to IOUs. To effectively provide IRP-related data for public utilities, mechanisms need to be established for data development and collection, reliability checks, storage, retrieval, and dissemination. The resulting data and related support services must be readily accessible by the nation's publics. 


\section{Participants}

Although this strategy would be useful to the majority of all public utilities, it should be targeted at smalland medium-sized utilities. These utilities generally lack the resources required for extensive internal data development. Additionally, they may have less access to existing data sources (e.g., they are not likely to be EPRI members) or may have less in common with the IOUs whose data resides in existing data banks. An IRP-related data bank for public utilities should be established by one or more national or regional key participants, such as APPA, NRECA, and/or the federal power agencies.

\section{Barriers Addressed}

This strategy is directly applicable for addressing two barriers to greater IRP implementation by public utilities. Establishing an IRP data bank for public utilities directly addresses the unavailable/unreliable data barrier. Additionally, the transfer of reliable data from other utility IRP experiences can help to address the lack of knowledge/experience barrier.

\section{Financial Assistance/Incentives}

Financial assistance supplements public utility financial resources by providing monetary support for IRP-related activities. A number of interview participants indicated that, because of their limited budgets, financial assistance would be beneficial to public utilities considering IRP. Financial assistance is most applicable for cost-intensive aspects of IRP, which include analytical studies and implementation. However, financial assistance may also be provided in other areas, such as for IRP education. For example, one interview participant suggested that financial assistance be provided to public utility personnel for attending regional or national IRP training programs.

Incentives should be provided to spur increased utility IRP activity. Incentives motivate action by offering an opportunity for rewards or by creating potential penalties. Although the topic of utility financial incentives has received increased attention of late, most efforts have been directed at IOUs and are not particularly transferable to public utilities. Several interview participants expressed an interest in IRP incentives, and one participant emphasized that incentives are different for publics. Incentives that are tailored to the unique and diverse characteristics of the public utility sector are an effective strategy for advancing IRP implementation. DOE is currently funding an APPA project to examine a variety of incentive/ financing mechanisms to encourage DSM in public power. The results of this project may be generally transferable to the IRP arena.

\section{Delivery Mechanisms}

Financial assistance and incentives should be provided via a variety of mechanisms, including those discussed below. Some of the mechanisms presented may require statutory changes, changes in bylaws or rules, memorandums of understanding, or other action.

- Grants: provide direct monetary support for IRP-related activity. Grants are usually provided based on selective criteria or a competitive process because no repayment is involved. APPA's DEED (Demonstration of Energy-Efficiency Developments) grant program recently supported the Moorhead, Minnesota, Public Service Department's sponsorship of a university student to develop an IRP for a public utility.

- Loans/financing: provides public utilities with funds for IRP studies or implementation. These funds can be repaid over an extended time frame. Many financing mechanisms exist, and access to these mechanisms varies by utility type. Since traditional public utility financing mechanisms (e.g., REA 
loans and bond financing) are generally used only for acquiring supply-side resources, this strategy should address broader application of such financing for nontraditional resource options such as demand-side resources. For example, the REA should consider extending long-term financing to cooperatively owned utilities for demand-side resources ${ }^{10}$ and the expanded use of bond financing for nontraditional resources should be further investigated for government-owned utilities. Various financing strategies that can supplement public utility financial resources include no- or low-interest loans and revolving loan funds. For example, the Municipal Energy Agency of Nebraska (MEAN) obtained state energy office grant funds and established a revolving loan fund for its distribution members. Members receive loans to purchase load management equipment, and the loans are paid back out of the resulting savings.

- Cost-sharing/leveraging: provides financial support predicated on resource contributions (i.e., money or other in-kind support) by the participating utilities. For example, WAPA has provided cost-shared assistance for the development of DSM projects and frequently leverages its technical assistance services through matching contributions of customer resources.

- Rate incentives/surcharges: provide price signals to encourage IRP activity by public utilities. Rate incentives reward public utilities for enhanced IRP efforts, but surcharges penalize utilities for a lack of effort. For example, BPA can apply surcharges for preference customers who have not implemented efficiency measures. The Energy Policy Act of 1992 amended The Hoover Power Plant Act to include a provision for WAPA to establish a surcharge for any customer not complying with the IRP regulations.

- Conservation transfers: are defined as any method whereby power saved by one entity is made available to another entity as a source of power. This incentive mechanism could be implemented by a federal power agency, or other major wholesalers, through a contractual arrangement with a customer to repurchase wholesale power saved through the customer's application of DSM. BPA has explored conservation transfers involving preference customers desiring to sell conserved federal electricity to an IOU.

- Power pools: can be established as an incentive for customers to meet high standards of IRP performance. A federal power agency or other wholesaler can create an incentive pool of electricity that is available to reward selected customers. This mechanism addresses the concerns of one interview participant who said, "The federal government must provide incentives for IRP and conservation. One idea is to [reward] savings with additional [lower-cost federal] power."

\section{Participants}

IRP-related financial assistance and incentives should be directed at the entire public utility sector; however certain assistance mechanisms are more applicable to specific subgroups than are others. For example, grants and cost-sharing should be targeted at small- and medium-sized public utilities, while financing mechanisms should be directed at larger utilities. The delivery of financial assistance services can be accomplished by all of the key public utility participants, although incentives are most likely to be provided by the federal power agencies.

\footnotetext{
${ }^{10}$ REA has an ERC loan program for cooperative fmancing of consumer-owned DSM equipment. However, REA does not currently loan funds for utility acquisition of DSM resources other than direct load control hardware.
} 


\section{Barriers Addressed}

As illustrated in Figure 6, this strategy can be applied to help overcome three of the barriers to greater IRP implementation. Financial assistance is most directly applicable to the limited financial and personnel resources barrier, while incentives address the barriers of surplus electrical resources and conservative attitudes of boards and other management.

\section{Regulatory Mandates}

Mandatory IRP requirements would lead to a direct increase in public utility IRP activity. Regulatory mandates appropriately designed and effectively implemented may be an effective strategy for encouraging IRP in this utility sector. Any such mandates should recognize the diversity of the public utility sector, as well as the unique attributes that distinguish them from IOUs.

\section{Delivery Mechanisms}

Mechanisms for mandating the practice of IRP by public utilities include

- Legislation: consists of national or state requirements for public utilities, or particular subgroups of publics, to conduct IRP. The Energy Policy Act of 1992 includes legislation to require IRP of all public utilities who receive power from WAPA, and also requires TVA to practice IRP.

- Contract terms: are clauses within power sales contracts that require IRP activity. For example, SWPA recently developed an IRP clause to include in all new or updated contracts and WAPA is proposing a contractual IRP requirement for all of its customers.

- Rulemaking: involves the development of IRP requirements, which are promulgated as a formal rule. Several state PUCs have used the rulemaking process to require public utility IRP.

- Procedures: are requirements that must be followed to remain in compliance with a particular contract or agreement. Such procedures can include IRP provisions. For example, REA's procedures for utilities seeking financial assistance include various IRP components.

\section{Participants}

Regulatory mandates for IRP can be targeted at any or all public utilities, depending on the regulatory mechanism applied. Legislation can be applied at a national or state level, and can be targeted to all public utilities. The effectiveness of state regulatory action as a strategy for promoting public utility IRP depends on the number of states with resource planning jurisdiction over publics. Contract terms are most likely to be developed by federal power agencies and targeted at their customers. However, they are not likely to be highly effective for those agencies that provide only a small percentage of their customers' electrical resources (e.g., APA, SEPA, and SWPA). Rulemaking can be accomplished by state PUCs, but can be targeted only at public utilities that fall under state jurisdiction. Procedures can be promulgated by any organization having contracts or agreements with public utilities, such as REA. 


\section{Barriers Addressed}

Regulatory mandates represent a major driver for increased IRP activity. In addition, they can directly address two barriers to greater IRP implementation (see Figure 6). First, well-designed regulations can help overcome the nonintegrated organizational structure barrier by explicitly encouraging joint IRP activity between power suppliers and their members. Second, this strategy addresses the barrier presented by conservative boards and managers. 



\section{Conclusion}

Integrated resource planning (IRP) is an approach to utility resource planning that integrates the evaluation of supply- and demand-side options for providing energy services at the least cost. Although IRP is being practiced by an increasing number of electric utilities, evidence shows that IRP is much more prevalent for IOUs than for public utilities. This is because considerable resources have been applied for the advancement of IRP in the IOU sector, including regulatory mandates and financial incentives.

Public utilities sell about $25 \%$ of the nation's electric energy. Thus, a proportionate share of the nation's IRP-related resources (e.g., human and financial resources) should also be directed at the public utility sector. These utilities may not require the same IRP-related regulatory mandates and financial incentives as IOUs, because of their locally controlled, nonprofit status. However, they could benefit greatly from education and information dissemination services, technical and financial assistance, and the development of methods, tools, and data.

Several strategies for advancing IRP principles and practices in the public utility sector are presented in this study. Although some organizations are currently implementing many aspects of these strategies, the fact that most of the nation's public utilities do not practice IRP is evidence that the resources applied to advance IRP in this sector are insufficient.

The strategies presented in this study are directed at supporting and expanding current IRP-related services for public utilities. Because these strategies provide the framework for an expanded and coordinated IRP advancement effort in the public utility sector, a more comprehensive development of the various strategies that recognize the diversity of this sector will be required to advance IRP to the fullest practical extent. This will require greater coordination among the various key participants to maximize the benefits of all available resources. 



\section{References}

American Public Power Association (APPA). (No date [n.d.]) The Public Benefits of Public Power. Work performed by American Public Power Association, Washington, DC.

American Public Power Association (APPA). (n.d.) Public Power in America: A History. Work performed by American Public Power Association, Washington, DC.

American Public Power Association (APPA). (1992). Public Power Magazine: Annual Statistical Issue. Washington, DC. January-February.

Clarence Council, Manager of Energy Services, WAPA. (1992). Personal telephone conversation. July.

Crenshaw, E.B., Supervisor of Contracts and Rates, SEPA. (1992). Personal telephone conversation. July.

Edison Electric Institute. (1992). IRP Sourcebook, 1992. Edison Electric Institute.

Electric Power Research Institute and Barakat, Howard and Chamberlain, Inc. for EPRI. (1987). Moving Toward Integrated Resource Planning; Understanding the Theory and Practice of Least-Cost Planning and Demand-Side Management/EM-5065. February.

Goldman, C., Hirst, E., and Krause, F. (1989). "Least-Cost Planning in the Utility Sector: Progress and Challenges." Washington, DC: U.S. Department of Energy; Berkeley, CA: Lawrence Berkeley Laboratory; Oak Ridge, TN: Oak Ridge National Laboratory. May.

Hinshaw, Annette. (1992a). Power Marketing Customers-Statistics. Southwestern Power Administration.

Hinshaw, Annette, Public Utilities Specialist, SWPA. (1992). Personal telephone conversation. July.

Lange, Mary, Public Utility Specialist, BPA. (1992). Personal telephone conversation. July.

Martin, Gerald, Energy Conservation Officer, SWPA. (1992). Personal telephone conversation. July.

Maxwell, Lynn, Manager of Resource Planning, TVA. (1992). Personal telephone conversation. July.

Moline, Barry. (1992a). Demand-Side Management in Public Power-The Quiet Revolution-Findings from a Survey of Publicly Owned Utilities. American Public Power Association, Washington, DC. January.

Moline, Barry, Manager of Demand-Side Programs, APPA. (1992b). Personal telephone conversation. July.

Morlan, Terry, and Nybo, James. (1993). Conservation Planning and Accomplishments in the Pacific Northwest. Northwest Power Planning Council.

National Rural Electric Cooperative Association (NRECA). (1985). Preference for the People. Washington, DC: National Rural Electric Cooperative Association. 
National Rural Electric Cooperative Association (NRECA). (1990a). Rural Electric Sourcebook. Washington, DC: National Rural Electric Cooperative Association.

National Rural Electric Cooperative Association (NRECA). (1990b). NARUC Annual Report on Utility and Carrier Regulation, 12/31/1990. Washington, DC: National Rural Electric Cooperative Association.

National Rural Electric Cooperative Association. (1991a). The G\&Ts-Power Providers for America's Rural Electric System. Work performed by National Rural Electric Cooperative Association, Washington, DC. January.

National Rural Electric Cooperative Association. (1991b). Facts About America's Rural Electric Systems. Work performed by National Rural Electric Cooperative Association, Washington, DC. January.

NEOS Corporation. (1990). Technical Assistance for G\&AC Revision. Worked performed by NEOS Corporation, Lakewood, CO: Western Area Power Administration.

NEOS Corporation. (1992). Technical Assistance for the Arizona Power Authority and Colorado River Commission. Worked performed by NEOS Corporation, Lakewood, CO: Western Area Power Administration. April.

Oldak, Mike, Regulatory Counsel, NRECA. (1992). Personal telephone conversation. July.

Olivier, Dave, Economic Data Base Manager, NRECA. (1992). Personal telephone conversation. July.

Puga, N. and Swank, D. (1992). "Joint Action for Demand-Side Management." Public Power; pp. 14-18. July-August.

Rural Electrification Administration, U.S. Department of Agriculture (1992). General and Pre-Loan Policies and Procedures Common to Insured and Guaranteed Electric Loans; Final Rule. 7 CFR Part 1710. Federal Register. Washington, DC. January 9.

Southeastern Power Administration. (1990). Forty Going on Fifty-1990 Annual Report. Southeastern Power Administration: Elberton, GA.

Western Area Power Administration. (1991a). Annual Report, 1991. Golden, CO: Western Area Power Administration.

Western Area Power Administration. (1991b). Annual Report, 1991. Statistical Appendix. Golden, CO: Western Area Power Administration.

Western Area Power Administration. (1992). "Tentative Preferred Alternative Announced." Western Area Power Administration Update; pp. 1-2. June.

Willis, Scott, Power Management Specialist, APA. (1992). Personal telephone conversation. July. 


\section{Bibliography}

American Public Power Association. (November 1990). Joint Action Agency Survey: Preliminary Results. Washington, DC.

American Public Power Association. Public Power Facts. Work performed by American Public Power Association, Washington, DC.

Beck, R.W. (June 1992). Model Plan for Energy Efficiency. Work performed by R.W. Beck and Associates, Sacramento, CA: California Municipal Utilities Association.

Bonneville Power Authority. (1991). 1990 Fast Facts for Bonneville Power Authority. Portland, OR: Bonneville Power Authority.

Electrical World. (1991). Directory of Electric Utilities-99th Edition. New York: McGraw-Hill 1991.

Hirst, Eric and Goldman, Charles. (1989). "Review of Demand-Side Data Needs for Least-Cost Utility Planning." Energy, Vol. 15, No. 5.

Morlan, Terry, Manager of Demand Forecasting, Northwest Power Planning Council. (July 1992). Personal telephone conversation.

National Rural Electric Cooperative Association. (November 1985). Preference for the People. Work performed by National Rural Electric Cooperative Association, Washington, DC.

National Rural Electric Cooperative Association. (July 1992). Rural Electrification Magazine. Washington, DC, Volume 51, Number 10.

National Rural Electric Cooperative Association. History and Organization of Rural Electrification. Washington, DC.

National Rural Electric Cooperative Association. Ten Questions and Answers about Integrated Resource Planning (IRP). Work performed by National Rural Electric Cooperative Association, Washington, DC.

Stewart, Bill, Program Manager for Energy Efficiency and IRP Programs, SEPA. (July 1992). Personal telephone conversation.

Shultz, George, Chief of Energy Forecasting Branch, REA. (July 1992). Personal telephone conversation.

Tennessee Valley Authority. (1991). Tennessee Valley Authority Annual Report-1991. Tennessee Valley Authority. 



\section{Appendix A}

Glossary of Terms 

American Public Power Association (APPA): A service organization based in Washington, DC, which represents the economic and political interests of the nation's local government-owned electric systems.

Banks for Cooperatives (BC): Authorized by Congress to lend money to rural utilities, BCs lend concurrently with REA, providing financing in conjunction with the guaranteed loan program which includes refinancing of Federal Financing Bank loans.

Capital Credits: Funds credited to rural electric cooperative members that equate to their ownership equity in the system.

Cooperative Finance Corporation (CFC): Created in 1969 by the nation's rural electric cooperatives, the National Rural Utilities Cooperative Finance Corporation (CFC) provides supplemental financing for rural electrification from private nongovernment sources.

Cooperatively Owned Utilities: Rural electric cooperatives, which include both distribution cooperatives and generation and transmission (G\&T) cooperatives.

Demand-Side Management (DSM): Planning, implementing, and monitoring those utility activities designed to influence customer use of electricity in ways that will produce desired changes in the utility's load shape. DSM is designed to produce changes in the time pattern and magnitude of a utility's load.

Distribution Cooperatives: Rural electric cooperatives that deliver electricity to residential and other consumers generally located in rural America. Distribution cooperatives are member owned and originated in the 1930s to bring power to rural America.

Externalities: Externalities associated with electrical power production and use are costs to society not already incorporated in the price of electric services.

Federal Power Agencies: U.S. government agencies involved in the generation, transmission, and/or distribution of electricity.

Gigawatt-hours (GWh): One million kilowatt-hours.

Government-Owned Utilities: All utilities owned by federal, state, or local governments. These utilities can be broken into five major subcategories: federal, state, municipal, joint action agency, and other (e.g., public utility districts and irrigation districts).

G\&T Cooperatives: "Generation and transmission" cooperatives (also known as power supply cooperatives) are power suppliers owned by several individual rural electric distribution cooperatives. Generally, they are responsible for supplying all of the power needed by their distribution cooperative members and do so by either generating the power or procuring it contractually from public or investor-owned organizations.

Indian Power Authorities: Electric utilities owned and operated by Indian nations.

Integrated Resource Evaluation: A component of IRP that compares supply- and demand-side resources to select a final resource mix. The comparative evaluation should allow equal consideration of both supply- and demand-side resource options. 
Integrated Resource Planning: An approach to utility resource planning that integrates the evaluation of both supply- and demand-side options for providing adequate, reliable, safe energy services at the least cost.

Investor-owned Electric Utilities (IOU): Electric utilities organized as tax-paying businesses usually financed by the sale of securities in the free market, and whose properties are managed by representatives regularly elected by their shareholders.

Irrigation Districts: Quasimunicipal utilities formed to serve primarily agricultural loads, particularly irrigation. Some are known as electrical districts or water districts.

Joint Action Agencies: Regional organizations formed by groups of utilities (typically by municipals) to jointly build or finance generation and transmission systems, and share other services.

Load Forecasting: Estimating future annual electricity use and peak demand to help electric utilities make resource allocation decisions.

Municipal Electric Utilities (Municipals): Electric utilities owned and operated by local governments or municipalities.

National Rural Electric Cooperative Association (NRECA): A nonpartisan and nonprofit organization, owned and controlled by the rural electric systems that make up its membership. NRECA was established as a service organization for its members in which activities are coordinated, problems solved, and services shared.

National Rural Utilities Cooperative Finance Corporation (CFC): A self-help financing institution developed out of a need for additional funding for the rural electrification program. CFC serves as the primary source of private financing for the program and supplements financing provided by the REA.

Public Utility Sector: Public utilities include government-owned (e.g., federal, state, municipal, joint action agency, and other) and cooperatively owned (e.g., distribution coops and G\&T coops) utilities.

Power Marketing Administration (PMAs): Federal power agencies, including APA, BPA, SEPA, SWPA, and WAPA, which market electric power and energy generated from federal projects.

Public Involvement: A component of IRP that allows for input from groups and individuals from outside the utility. These outside representatives ensure that a broader range of interests and potential resource options will be made known to utility decision makers.

Public Power Districts (PPDs): Public political entities (similar to school districts) formed to provide power to rural areas.

Public Utility Districts: Public political entities (similar to school districts) formed to provide power to local areas. Some are known as people's utility districts.

Rural Electrification Administration (REA): A federal agency created to provide loans for rural electrification. It also provides technical assistance when needed to support the security of the loans. The term REA is often used erroneously as a synonym for the locally owned cooperatives whose growth has been financed with loans from the agency. 
Rural Electric Cooperatives: Consumer-owned utilities established to provide electric service to rural America. See distribution cooperatives and G\&T cooperatives.

State Power Authorities: State-owned utilities involved in the generation, transmission, and/or distribution of electricity.

Supply-Side Resource Evaluation: Evaluating supply resources for meeting an electric utility's future resource requirements. A supply-side resource assessment may include examining of a range of resources, including purchased power, alternative/renewable resources, life extension and repowering of existing plants, utility construction of power plants, and new or upgraded transmission facilities.

Territorial Power Authorities: Electric utilities owned by U.S. territories.

Uncertainty Analysis: A component of IRP that analyzes a variety of possible future conditions and the options available to deal with them. An uncertainty analysis provides information about the relative risks of alternative resource strategies. Its primary purpose is to facilitate better resource planning decisions that reduce risk. 



\section{Appendix B}

\section{State Regulation of Public Utilities}



Table B-1. State Regulation of Public Utilities

\begin{tabular}{|c|c|c|c|c|}
\hline 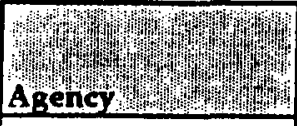 & 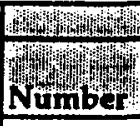 & 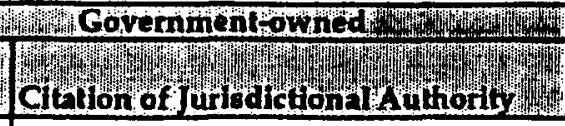 & 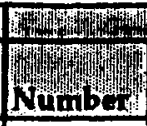 & 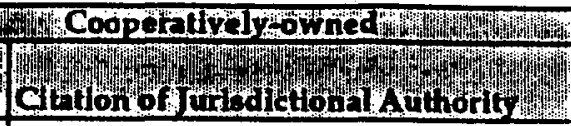 \\
\hline Alabama PSC & 0 & & 0 & \\
\hline Alaska PUC & & s6, Ch 113 SLA 1970 & 9 & s6, Ch 113 SLA 1970 \\
\hline Arizona CC & & No jurisdiction & 11 & Art. XV, AZ Constitution \\
\hline Arkansas PSC & 15 & Safety only & 19 & A.C.A. 23-18-308 \\
\hline California PUC & 0 & $\begin{array}{l}\text { CA PU Code s8029.5-8057, limited } \\
\text { jurisdiction }\end{array}$ & 4 & PU Code $216,217,218,2777$ \\
\hline Colorado PUC & 16 & $s 40-1-103$ CRS 1973 & 28 & S 40-1-103 CRS 1973 \\
\hline Connecticut DPUC & 0 & & 0 & \\
\hline Delaware PSC & 0 & & 1 & DE Code, Title 26 \\
\hline DCPSC & 0 & & 0 & \\
\hline Florida PSC & 34 & Ch. 366 (limited) & 17 & Ch. 366 (limited) \\
\hline Georgia PSC & & Title 46 territory only & 43 & Title 46 territory/finance \\
\hline Hawaii PUC & 0 & & 0 & \\
\hline Idaho PUC & $\mathbf{0}$ & & 0 & \\
\hline IIlinois CC & & No jurisdiction & & No jurisdiction \\
\hline Indiana URC & 50 & IC 8-1-2-1 et seg. & 46 & IC $8-1-13-18,8-1-2-1$ \\
\hline Iowa UB & 112 & IA Code Ch 476 \& 478 & 56 & LA Code Ch 476 \& 478 \\
\hline Kansas SCC & 14 & Ch 66, KS Stat. Ann. & 35 & Ch 66, KS Stat. Ann. \\
\hline Kentucky PSC & 0 & & 24 & Ch. 278, KY Rev. Stats. \\
\hline Louisiana PSC & 0 & Revised Stautes & 16 & RS 12:409(g)417.1, Const. \\
\hline Maine PUC & 6 & 35-A MRSA & 5 & 35-A MRSA \\
\hline Maryland PSC & 5 & Article 78 & 4 & Article 78 \\
\hline Massachusetts DPU & 40 & Chapter 164 (limited) & 0 & \\
\hline Michigan PSC & 0 & & 13 & Act 106, PA 1909, Amended \\
\hline Minnesota PUC & 126 & Ch. $216 \bar{B}(1974)$ & 54 & Ch. 216B (1974) [3] \\
\hline Mississippi PSC & 21 & PU Act 1956 (Amended), PU Act 1983 & 28 & PU Act 1956 (Amended), PU Act 1983 \\
\hline Missouri PSC & 0 & & 0 & \\
\hline Montana PSC & 2 & Title 69, Ch. 7, MCA & 0 & \\
\hline Nebraska PSC & & No jurisdiction & & No jurisdiction \\
\hline Nevada PSC & 0) & & 11 & NRS 704.673-704.677 \\
\hline New Hampshire & 3 & $\begin{array}{l}\text { RSA } 362: 2 \text { Outside municipal limits } \\
\text { only }\end{array}$ & 1 & RSA 362:2 \\
\hline New Jersey BPU & 1 & Limited jurisdiction & & NJSA 48:2-13, et. seg. \\
\hline New Mexico PSC & 0 & NMSA 1978, s62-6-5 & 20 & NMSA 1978, s62-8-7 \\
\hline New York PSC & $3[4]$ & $\begin{array}{l}\text { Pub. Service Law, s2(16), 5(1)(b) and } \\
\text { Art } 4\end{array}$ & 5 & Rural Elec. Co-op Law $s 67$ \\
\hline North Carolina UC & $2[5]$ & & & NC GS Ch. 62, 110.2 et seg. \\
\hline North Dakota PSC & $\overline{0}$ & & 0 & \\
\hline Ohio PUC & 0 & & 0 & \\
\hline Oklahoma CC & 0 & & 31 & Title 17, s158.21 et seq \\
\hline Oregon PUC & 4 & & 19 & Safety, area, curtainment \\
\hline Pennsylvania PUC & 4) & & 0 & \\
\hline Rhode Island PUC & & Title 39, Ch. 2 & & \\
\hline South Carolina PUC & 0 & & 0 & \\
\hline South Dakota PUC & 34 & $\begin{array}{l}49-34 \mathrm{~A} \text { and } 49-41 \mathrm{~B} \text { territory \& siting } \\
\text { only }\end{array}$ & 35 & $\begin{array}{l}49-34 \mathrm{~A} \text { and } 49-41 \mathrm{~B} \text { territory \& siting } \\
\text { only }\end{array}$ \\
\hline Tennessee PSC & 0 & & 25 & 67-901 for Ad Valorem assessment only \\
\hline Texas PUC & 71 & VTCS, Art. 1446c & 86 & VTCS, Art. 1446c \\
\hline Utah PSC & 1 & UT Code, s17-6-1.1 & 10 & UT Code, s54-2-1(19) \\
\hline Vermont PSB & 15 & 30 VSA & 2 & 30 VSA \\
\hline Virgin Islands PSC & & Title 30, VC, s1 Amended & [7] & \\
\hline Virginia SCC & 0 & & 13 & VA Code, Title 56 \\
\hline Washington UTC & 0 & & 0 & \\
\hline West Virginia PSC & 2 & & 3 & WV Code, Ch. 24 \\
\hline Wisconsin PSC & 82 & Ch. 196 & 0| & \\
\hline Wyoming PSC & 17 & s37-1-101 Outside municipal limits only & 1]s & 337-1-101 WY Stats 1977 \\
\hline
\end{tabular}

Source: NARUC Annual Report on Utility and 
Notes for Table B-1:

1. The rates of only one of the coops are under commission regulation; Colorado still regulates the certificates and service territories of all cooperatives. The state commission has jurisdiction over municipal utilities only outside corporate limits, and then only if rates charged outside corporate limits differ from rates charged inside corporate limits.

2. One small municipal electric plant on Cuttyhunk Island was exempted from department jurisdiction under a 1936 act of legislature.

3. Gas and electric regulation was established on April 12, 1974; rate regulation was effective January 1, 1975.

4. Plus 41 is under the jurisdiction of the New York Power Authority. Public Authorities Law (s1014) exempts the Power Authority from regulation by the commission except for siting transmission and generation facilitators under Article 7 and 8 s18(a) of the Public Service Law. Municipalities that buy power from the Power Authority are also exempt from regulation by the PSC under Power Authorities Law (s1005[5][g]).

5. Applies to two state-owned facilities only.

6. Municipals may elect commission regulation. Certification required of all retail public utilities, including municipalities and political subdivisions. Two state-affiliated river authorities under PUC jurisdiction for rates.

7. Commission did not respond to requests for update information; these data may not be current. 


\section{Appendix C}

\section{Representative Sample of Public Utilities:}

Selection Criteria and Data Base 



\section{Selection Criteria for Representative Sample of Public Utilities}

The following criteria are used to select a sample of $30^{1}$ public utilities that represent this entire utility sector. The selected sample reflects the general characteristics of this sector, and specific IRP considerations. The criteria are

1. Utility Type: The sample reflects the actual percentage mix of the various types of public utilities (e.g., government-owned and cooperatively owned). However, the number of joint action agencies and G\&T cooperatives contacted was increased (relative to their members) to reflect their resource planning responsibilities.

2. Size: Because the average public utility has annual sales of about $200 \mathrm{GWh}$, approximately half of the selected utilities have annual sales of $\leq 200 \mathrm{GWh}$, and half have annual sales of $\geq 200 \mathrm{GWh}$.

3. Federal Power Agencies: The selected utilities reflect the actual percentage of public utilities served by the federal power agencies.

4. Geography: The selected utilities reflect a geographical mix.

5. Generation: The selected utilities include a mix of generating and nongenerating utilities.

6. IRP: Approximately one-third of the selected utilities currently practice IRP. A disproportionate number of these utilities were chosen because of the critical insights they would provide.

\footnotetext{
${ }^{1}$ Thirty public utilities were selected and contacted. Responses were received from the 29 utilities listed in Table C-1. 
Table C-1. Profile Data Base for Representative Sample of Public Utilities

\begin{tabular}{|c|c|c|c|c|c|c|c|c|c|c|c|c|c|}
\hline \multirow{3}{*}{ W } & \multirow{3}{*}{ sty } & \multirow{3}{*}{ प्रफ़: } & \multirow{3}{*}{\multicolumn{3}{|c|}{ 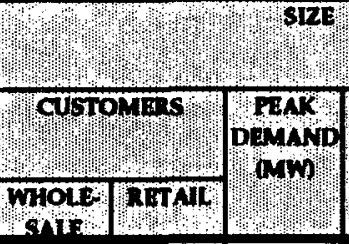 }} & \multirow{3}{*}{ Whanm } & \multirow{3}{*}{ 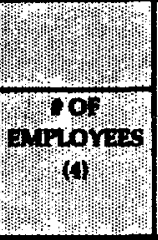 } & \multirow{3}{*}{ Whaspy } & \multicolumn{2}{|c|}{ 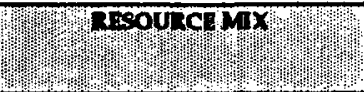 } & \multirow{3}{*}{ Foprat rower } & \multicolumn{2}{|c|}{ ग) } \\
\hline & & & & & & & & & GENiration & Trirctinses!l & & \multirow{2}{*}{ CuRRanthy } & \multirow{2}{*}{ 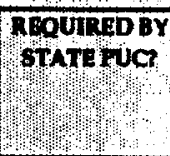 } \\
\hline & & & & & & & & & 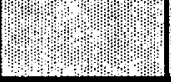 & 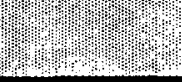 & & & \\
\hline Allesheny Electric Coopentive, Inc. & $\mathbf{P A}$ & GET & $14(2)$ & $0(2)$ & 150(2) & $2.236(2)$ & 70 & NONE & $1,393(2)$ & $843(2)$ & No & No & No \\
\hline Altamont Municipal Electric Department & KS & MUNI & a(1) & 513(1) & $2(1)$ & 6(1) & 3 & NONE & NONE & $7(1)$ & No & Yes & No \\
\hline Amherst Utilities Department & $\mathrm{OH}$ & MUNI & Q(1) & $3,802(1)$ & $14(1)$ & $57(1)$ & 5 & AMPO(3) & $61(1)$ & NONE & No & No & No \\
\hline Arizonn Electric Power Cooperative, Ins: & $\mathbf{A z}$ & GLT & $7(2)$ & $0(2)$ & $462(2)$ & $2,766(2)$ & 300 & APPA(3) & $2.459(2)$ & $389(2)$ & WAPA & Yes: & Yes \\
\hline Bin Flat Electric Cooperative, Ine. & MT & COOP & Q(1) & $1,544(1)$ & $B(1)$ & $4(1)$ & 9 & CMPC(4) & NONE & $48(1)$ & No & No & No \\
\hline Brietal Utilitice Board & VA & MUNI & Q(2) & $14,214(2)$ & $108(2)$ & 479(2) & 65 & DRPA(3) & NONE & $\operatorname{son}(2)$ & TVA & No & No \\
\hline Burfington Electric Department & vT & MUNI & $o(1)$ & $18,002(1)$ & $65(1)$ & $106(1)$ & 174 & NONE(3) & 99(1) & 389(1) & No & Yes & Yes \\
\hline Churach Electric Assaciation, Inc. & $\mathbf{A K}$ & COOP & 4(2) & $62,832(2)$ & $362(2)$ & $2.052(2)$ & 350 & NONE(4) & $2,107(2)$ & $105(2)$ & $\overline{A P A}$ & Yes & Yes \\
\hline Columbia Water \& Light Department & Mo & MUNI & O(2) & $26959(2)$ & $162(2)$ & $619(2)$ & 188 & MIMEUC(3) & $63(2)$ & $603(2)$ & No & Yee & No \\
\hline Dairyland Power Cooperative & $\mathbf{w I}$ & G\&T & $28(2)$ & $0(2)$ & 672(2) & $1,256(2)$ & 700 & NONE(4) & 3,880 & $555(2)$ & No & Yes: & Yea \\
\hline Eunene Water \& Electric Board & OR & MUNI & o(1) & $65253(1)$ & $470(1)$ & $2,371(1)$ & 460 & NONE(3) & $474(1)$ & $1,983(1)$ & BPA & No & No \\
\hline Eververeen Municipal Light Department & $\mathbf{A L}$ & MUNI & $O(2)$ & $1,898(2)$ & NL & $51(2)$ & 6 & NONE(3) & NONE & $57(2)$ & No & No & No \\
\hline Karnes Electric Cooperative, Inc. & TX & COOP & $O(2)$ & $11364(2)$ & $33(2)$ & $131(2)$ & 6 & STEC(4) & NONE & $147(2)$ & No & No. & No \\
\hline KC Electric Association & co & COOP & O(2) & $5767(2)$ & 52(2) & $142(2)$ & 29 & TSGTA(4) & NONE & $159(2)$ & No & No & No \\
\hline Little River Electric Cooperative, Inc. & sc & COOP & Ox2) & 9351(2) & NL & $108(2)$ & 25 & $\operatorname{SCEC}(4)$ & NONE & $115(2)$ & SEPA & No & No \\
\hline Los Angeles Department of Water and Power & CA & MUNI & O(2) & $, 321,128,2$ & $5,312(2)$ & $21,147(2)$ & 11,000 & SCPPA(3) & NL & $13,012(2)$ & WAPA & Yes & No \\
\hline Marblehead Municipal Light Department & $\mathbf{M A}$ & MUNI & o(1) & $10239(1)$ & $21(1)$ & 89(1) & 26 & MMWEC(3) & $3(1)$ & $80(1)$ & No & Yes & No \\
\hline Municipal Enemey Acency of Nebraksa & NE & InA & $55(2)$ & $0(2)$ & $109(2)$ & $830(2)$ & 20 & NONE & NONE & $689(2)$ & WAPA & Yes & No \\
\hline N.C. Municipal Power Arency & NC & LAA & $19(2)$ & g(1) & 1,138(1) & $7858(2)$ & 70 & NONE & $\$, 957(2)$ & $3,007(2)$ & No & No & No \\
\hline Plummer Electric Department & 10 & MUNI & O(2) & $827(2)$ & $6(2)$ & $28(2)$ & 5 & NONE(3) & NONE & $28(2)$ & No & No & No \\
\hline Public Utillity Dietriat Na. 2 of Grent County & WA & OTHER & O(2) & $31386(2)$ & 455(2) & $7,687(2)$ & 560 & CWPA(3) & 2,942(2) & $100(2)$ & BPA & No & No \\
\hline Southem Maryland Elestric Cooperative, Inc. & MD & COOP & Q(2) & $92.365(2)$ & 439(2) & $1.859(2)$ & 470 & NONE(3) & NONE & $1,935(2)$ & No & No & No \\
\hline Tennemene Valler Electric Cooperative & $\mathbf{T N}$ & COOP & $O(2)$ & $15251(2)$ & $75(2)$ & $260(2)$ & 60 & NONE(4) & NONE & $283(2)$ & TVA & No & No \\
\hline Thilaf River Falla Water \& Lingt Department & $\mathbf{M N}$ & MUNI & o(1) & 3799(1) & 19(1) & $98(1)$ & 26 & NMPA(3) & NL & 102(1) & WAPA & No & No \\
\hline Themasville Water \& Light Department & CA & MUNI & O(2) & $12.193(2)$ & $77(2)$ & $368(2)$ & 96 & MEAG(3) & NONE & $382(2)$ & SEPA & No & No \\
\hline Waverly Munisipal Electric Utility & IA & MUNI & O(2) & $3807(2)$ & $22(2)$ & $87(2)$ & 22 & NONE(3) & $39(2)$ & so(2) & No & Yes & No \\
\hline Wellton Mohawk Irrieation \& Drainare District & $\mathbf{A z}$ & OTHER & $\mathbf{N L}$ & NL & $\mathbf{N L}$ & $53(2)$ & 17 & NONE(3) & NONE & $161(2)$ & WAPA & No & No \\
\hline Wieconsin Public Powrer, Inc. Syetem & $\mathbf{W I}$ & IMA & $30(1)$ & Q(1) & $480(1)$ & $2,500(1)$ & 33 & NONE(3) & NONE & $2,500(1)$ & No & Yes & Ye: \\
\hline Yale Municipal Linth Department & oK & MUNI & $0(2)$ & $725(2)$ & $3(2)$ & $7(2)$ & 3 & OMPA(3) & NONE & $9(2)$ & SWPA & No & No. \\
\hline
\end{tabular}


Legend for Table C-1.

TYPE:

COOP: Distribution Cooperative

G\&T: Generation \& Transmission Cooperative

JAA: Joint Action Agency

MUNI: $\quad$ Municipality

OTHER: Other Government-Owned Utility

\section{PARENT UTILITY/ASSOCIATION:}
AMPO:
American Municipal Power-Ohio
APPA:
Arizona Power Pooling Association
BRPA:
Blue Ridge Power Agency
CMPC:
Central Montana Power Cooperative
CWPA:
Central Washington Power Authority
MEAG: $\quad$ Municipal Electric Authority of Georgia
MJMEUC: $\quad$ Missouri Joint Municipal Electric Utility Commission
MMWEC: Massachusetts Municipal Wholesale Electric Company
NMPA: $\quad$ Northern Municipal Power Agency
OMPA: Oklahoma Municipal Power Authority
SCEC: $\quad$ South Carolina Electric Cooperative
SCPPA: $\quad$ Southern California Public Power Authority
STEL: $\quad$ South Texas Electric Cooperative
TSGTA: $\quad$ Tri-State Generation \& Transmission Association

\section{SOURCES:}

(1) Electrical World. Directory of Electric Utilities-99th Edition. New York: McGraw-Hill, 1991; data reflect 1989 calendar year.

(2) Electrical World. Directory of Electric Utilities-99th Edition. New York: McGraw-Hill, 1991; data reflect 1990 calendar year.

(3) American Public Power Association. Public Power Magazine-Annual Statistical Issue. Washington, DC, January-February 1992.

(4) Telephone discussions conducted during August 12-September 15, 1992. 



\section{Appendix D}

\section{IRP Telephone Interview Instrument}





\section{IRP QUESTIONS FOR PUBLIC UTILITIES}

Hello, my name is Denise Rue/Cindy Garrick of NEOS Corporation. We are under contract with the National Renewable Energy Laboratory (formerly SERI) to conduct a scoping study to determine the integrated resource planning (IRP) activities and needs in the public utility sector. As part of this effort we are calling a sample of the nation's public utilities to ask a few questions about their IRP activities and needs. Do you have a few minutes to answer some questions on this subject? (IF NO, GET BETTER DATE AND TIME TO CALL BACK)

Q-1 Are you familiar with the term integrated resource planning (IRP)? (Circle number)

$1 \quad$ NO; IF NO, SKIP TO QUESTION 8

2 YES; If yes, could you give us your best definition of IRP:

Q-2 Do you know what the various components of an IRP are? (Circle number)

1 DON'T KNOW

2 YES; If yes, could you list them:

Q-3 What do you feel the benefits of IRP are?

Q-4 What do you feel the drawbacks of IRP are? 
Q-5 Does your utility currently practice IRP? (Circle number)

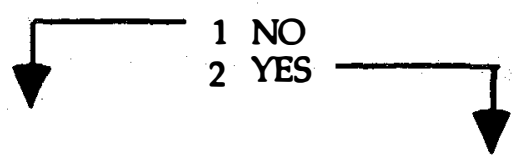

Q-6a What are the primary reasons you do not?

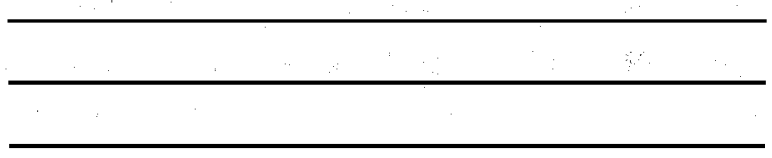

Q-7a What would prompt you to conduct an IRP?

Q-8 Does your utility develop a regular load forecast? (Circle number)

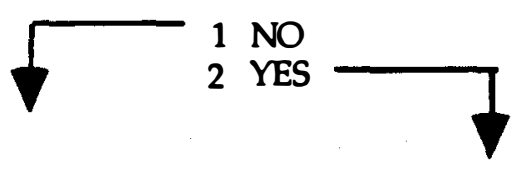

Q-9a If no, please explain:

Q-9b What department/individual conducts? 
Q-10 Does your utility evaluate supply-side resource options? (Circle number)

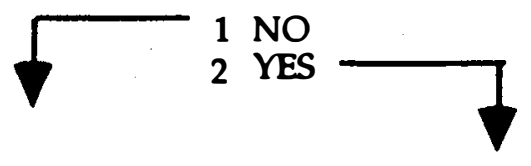

Q-11a If no, please explain:

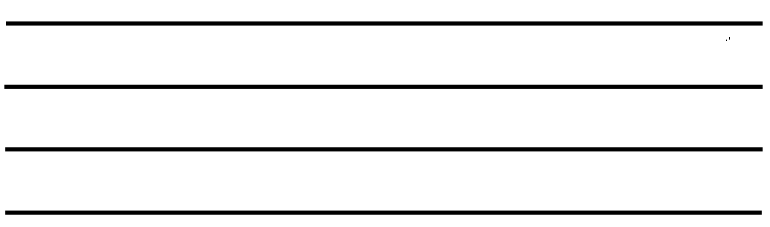

Q-11b If yes, what supply-side resource options do you evaluate?

Q-11c What department/individual conducts?

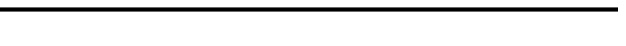

Q-12 Does your utility evaluate demand-side management options?(Circle number)

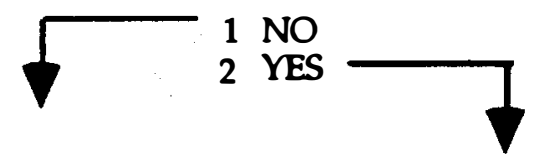

Q-13a If no, please explain:

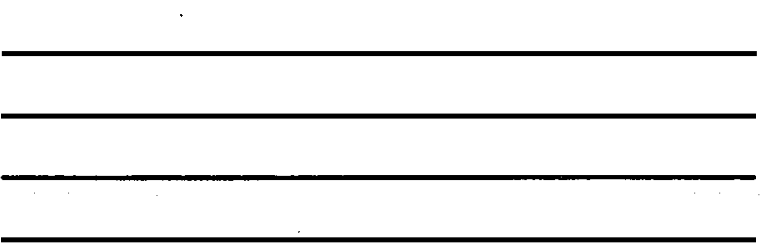

Q-13b If yes, what DSM options do you evaluate?

Q-13c What department/individual conducts? 
Q-14 Does your utility consider extemalities into the resource planning process?(Circle number)

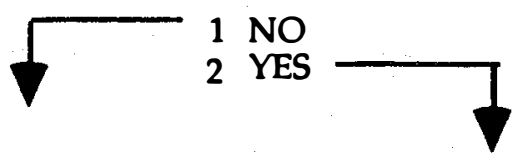

Q-15a If no, please explain:

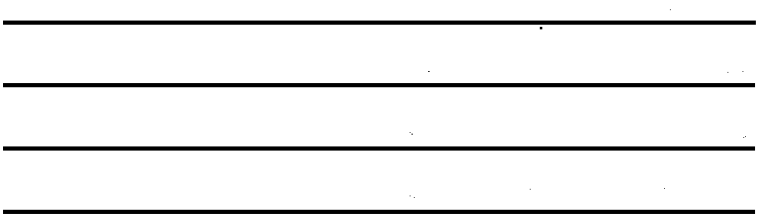

Q-15b What types of externalities do you consider and in what way?

Q-15c What department/individual conducts?

Q-16 Does your utility conduct an uncertainty analysis as part of the planning process?(Circle number)

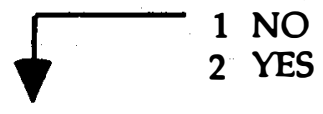

Q-17a If no, please explain:

Q-17b What types of risks/uncertainties are considered?

Q-17c What departmentindividual conducts? 
Q-18 Does your utility conduct an integrated resource evaluation as part of the planning process? (Circle number)

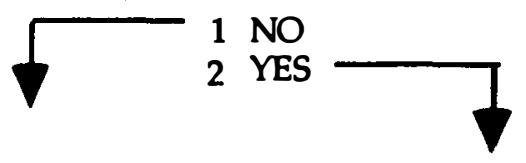

Q-19a If no, please explain:

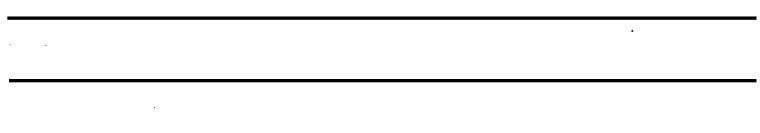

Q-19b If yes, how do you do this?

Q-19c What department/individual conducts?

Q-20 Does your utility involve the public in the resource planning process?(Circle number)

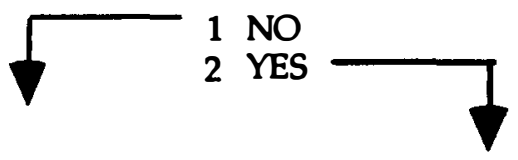

Q-21a If no, please explain:

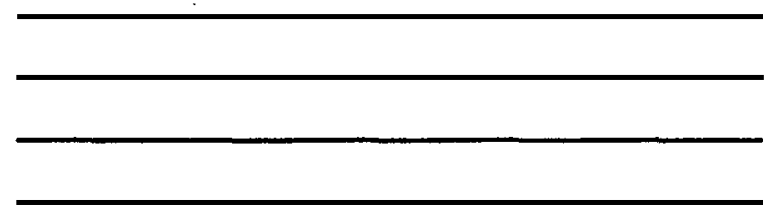

Q-21b If yes, what types of public involvement?

Q-21c What department/individual conducts?

Q-22 How many employees does your utility have? 
Q-23 What is, or would be, your opinion of regulations requiring IRP of consumer-owned utilities ?

Q-24 In your opinion, what is the biggest obstacle to adoption/greater adoption of IRP by consumer-owned electric utilities?

Q-25 What types of assistance would be most beneficial to consumer-owned electric utility adoption of IRP? 
Appendix E

\section{Public Utilities that Prepare IRPs}



Table E-1. Public Utilities that Prepare IRP*

\begin{tabular}{|c|c|}
\hline S\% & 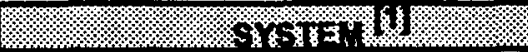 \\
\hline \multirow[t]{2}{*}{ AK } & City of King Cove \\
\hline & Chugach Electric Assoc. \\
\hline$\overline{A L}$ & AL Municipal Electric Authority \\
\hline \multirow[t]{5}{*}{$\overline{\mathbf{A Z}}$} & AZ Electric Power Coop. (7) \\
\hline & AZ Power Pooling Assoc. (4) \\
\hline & City of Mesa \\
\hline & City of Safford \\
\hline & Salt River Project \\
\hline \multirow[t]{10}{*}{$\overline{\mathrm{CA}}$} & Alameda Bureau of Electricity \\
\hline & City of Ansheim \\
\hline & Banning Electric Dept. \\
\hline & Burbank Public Service Dept. \\
\hline & Los Angeles Dept. of Water \& Power \\
\hline & Modesto Irrigation Dist. \\
\hline & City of Palo Alto \\
\hline & Riverside Public Utilities Dept. \\
\hline & City of Santa Clara \\
\hline & Turlock Irrigation Dist. \\
\hline \multirow[t]{2}{*}{$\mathrm{CO}$} & Lamar Utilities Board \\
\hline & Wray Municipal Light \& Power \\
\hline CT & CT Municipal Electric Energy Coop. (5) \\
\hline \multirow[t]{4}{*}{$\overline{F L}$} & Gainsville Regional Utilities \\
\hline & Jacksonville Electric Auth. \\
\hline & Orlando Utilities Comm. \\
\hline & City of Tallahassee \\
\hline$\overline{\mathbf{G A}}$ & Oglethorpe Power Corp. (39) \\
\hline$\overline{G U}$ & Guam Power Auth. \\
\hline \multirow[t]{6}{*}{ IA } & Cedar Falls Utilities \\
\hline & La Porte City Utilities \\
\hline & Osage Municipal Utilities \\
\hline & Panora Electric Dept. \\
\hline & Spencer Municipal Utilities \\
\hline & Waverly Light \& Power \\
\hline$\overline{\mathbf{I N}}$ & IN Municipal Power Agency (31) \\
\hline \multirow[t]{5}{*}{$\overline{\mathbf{K S}}$} & City of Altamont \\
\hline & Kansas City Board of Public Utilities \\
\hline & Wamego Light Dept. \\
\hline & City of Wellington \\
\hline & City of Winfield \\
\hline \multirow[t]{2}{*}{$\overline{\mathbf{K Y}}$} & East KY Power Coop. (18) \\
\hline & Big Rivers Electric Coop. (4) \\
\hline $\mathbf{L A}$ & LA Energy and Power Auth. (19) \\
\hline \multirow[t]{6}{*}{$\overline{\mathbf{M A}}$} & Braintree Electric Light Dept. \\
\hline & Holyoke Gas \& Electric Dept. \\
\hline & Littleton Electric Light Dept. \\
\hline & Marblehead Municipal Light Dept. \\
\hline & Reading Municipal Light Dept. \\
\hline & Westfield Gas \& Electric Light Dept. \\
\hline
\end{tabular}

\begin{tabular}{|c|c|}
\hline 3\% $1 \%$ & $\%=8,8=18 \%$ \\
\hline MD & Easton Utilities Comm. \\
\hline ME & Houlton Water Co. \\
\hline \multirow[t]{4}{*}{$\mathrm{MN}$} & City of Benson Light \& Water Dept. \\
\hline & Blue Earth Light \& Water Dept. \\
\hline & Hutchinson Utilities Comm. \\
\hline & Thief River Falls Water \& Light \\
\hline \multirow[t]{4}{*}{ MO } & Carthage Water \& Electric Plant \\
\hline & Columbia Water \& Light Dept. \\
\hline & Independence City Power \& Light \\
\hline & Shelbina Light \& Water Dept. \\
\hline MS & Municipal Energy Agency of MS (8) \\
\hline \multirow[t]{8}{*}{ NE } & Callaw ay Municipal Light Dept. \\
\hline & Grand Island Utilities Dept. \\
\hline & City of Grant \\
\hline & Howand Greeley Rural PPD \\
\hline & Hubbell Electric Dept. \\
\hline & Lincoln Electric System \\
\hline & Municipal Energy Agency of NE (53) \\
\hline & Wahoo Municipal Utilities \\
\hline \multirow[t]{2}{*}{ NM } & Los Alamos County Utilities \\
\hline & Springer Electric Dept. \\
\hline $\mathbf{N Y}$ & Plattsburgh Municipal Lighting Dept. \\
\hline$\overline{\mathrm{OH}}$ & City of Hamilton \\
\hline$\overline{\mathrm{OR}}$ & Emerald People's Utility Dist. \\
\hline \multirow[t]{3}{*}{$\overline{T X}$} & Austin Electric Utility Dept. \\
\hline & City of San Antonio \\
\hline & Texas Municipal Power Agency (4) \\
\hline \multirow[t]{2}{*}{$\overline{\mathbf{U T}}$} & Bountiful City Light \& Power \\
\hline & Monroe City Power \\
\hline \multirow[t]{8}{*}{ VT } & Burlington Electric Dept. \\
\hline & Hardwick Electric Dept. \\
\hline & Village of Hyde Park \\
\hline & Lyndonville Municipal Electric Plant \\
\hline & Morrisville Water \& Light Dept. \\
\hline & Northfield Electric Dept. \\
\hline & Stowe Electric Dept. \\
\hline & Washington Electric Coop. \\
\hline \multirow[t]{4}{*}{$\overline{\text { WA }}$} & Clark Public Utilities \\
\hline & PUD No. 1 of Lewis County \\
\hline & Seattle City Light \\
\hline & Tacoma Dept. of Public Utilities \\
\hline \multirow[t]{7}{*}{ WI } & Dairyland Power Coop. (28) \\
\hline & Menasha Electric \& Water Utilities \\
\hline & Reedsburg Utility Comm, \\
\hline & Stugeon Bay Utilities \\
\hline & Waterloo Light \& Water Comm. \\
\hline & Waunakee Water \& Light Comm. \\
\hline & WI Public Power, Inc. (30) \\
\hline
\end{tabular}

Source: APPA, NEOS, and REA

*The list is not all inclusive, however, it reflects the majority of public utilities involved in IRP.

[1] For joint action agencies and G\&Ts, the number of member distribution systems is indicated in parentheses. 


\begin{tabular}{|c|c|c|c|}
\hline $\begin{array}{l}\text { Document Control } \\
\text { Page }\end{array}$ & $\begin{array}{l}\text { 1. NREL Report No. } \\
\text { NREL-TP-462-5473 }\end{array}$ & $\begin{array}{l}\text { 2. NTIS Accession No. } \\
\text { DE93010036 }\end{array}$ & 3. Recipient's Accession No. \\
\hline \multirow{2}{*}{\multicolumn{3}{|c|}{$\begin{array}{l}\text { 4. Title and Subtitle } \\
\text { Scoping Study of Integrated Resource Planning Needs in the Public } \\
\text { Utility Sector }\end{array}$}} & $\begin{array}{l}\text { 5. Publication Date } \\
\text { June } 1993\end{array}$ \\
\hline & & & 6. \\
\hline \multicolumn{3}{|c|}{$\begin{array}{l}\text { 7. Author(s) } \\
\text { C.J. Garrick, J.M. Garrick, and D.R. Rue }\end{array}$} & 8. Performing Organization Rept. No. \\
\hline \multirow{2}{*}{\multicolumn{3}{|c|}{$\begin{array}{l}\text { 9. Performing Organization Name and Address } \\
\text { NEOS Corporation } \\
\text { 165 S. Union Blvd., \#260 } \\
\text { Lakewood, Colorado } 80228\end{array}$}} & $\begin{array}{l}\text { 10. Project/Task/Work Unit No. } \\
\text { AS115440 }\end{array}$ \\
\hline & & & $\begin{array}{l}\text { 11. Contract (C) or Grant (G) No. } \\
\text { (C) AE-2-121991 } \\
\text { (G) }\end{array}$ \\
\hline \multirow{2}{*}{\multicolumn{3}{|c|}{$\begin{array}{l}\text { 12. Sponsoring Organization Name and Address } \\
\text { National Renewable Energy Laboratory } \\
1617 \text { Cole Boulevard } \\
\text { Golden, Colorado } 80401-3393\end{array}$}} & $\begin{array}{l}\text { 13. Type of Report \& Period Covered } \\
\text { Subcontractor Report }\end{array}$ \\
\hline & & & 14. \\
\hline \multicolumn{4}{|c|}{$\begin{array}{l}\text { 15. Supplementary Notes } \\
\text { NREL Technical Monitor: B. Swezey }\end{array}$} \\
\hline \multicolumn{4}{|c|}{$\begin{array}{l}\text { Integrated resource planning (IRP) is an approach to utility resource planning that integrates the evaluation of } \\
\text { supply- and demand-side options for providing energy services at the least cost. Many utilities practice IRP; } \\
\text { however, most studies about IRP focus on investor-owned utilities (IOUs). This scoping study investigates the IRP } \\
\text { activities and needs of public utilities (not-for-profit utilities, including federal, state, municipal, and cooperative } \\
\text { utilities). This study (1) profiles IRP-related characteristics of the public utility sector, (2) articulates the needs of } \\
\text { public utilities in understanding and implementing IRP, and (3) identifies strategies to advance IRP principles in } \\
\text { public utility planning. }\end{array}$} \\
\hline \multicolumn{4}{|c|}{$\begin{array}{l}\text { 17. Document Analysis } \\
\text { a. Descriptors } \\
\text { integrated resource planning; public utilities; utility planning } \\
\text { b. Identifiers/Open-Ended Terms }\end{array}$} \\
\hline \multicolumn{4}{|l|}{$\begin{array}{l}\text { c. UC Categories } \\
233\end{array}$} \\
\hline \multirow{2}{*}{\multicolumn{2}{|c|}{$\begin{array}{l}\text { 18. Availability Statement } \\
\text { National Technical Information Service } \\
\text { U.S. Department of Commerce } \\
5285 \text { Port Royal Road } \\
\text { Springfield, VA } 22161\end{array}$}} & & $\begin{array}{l}\text { 19. No. of Pages } \\
86\end{array}$ \\
\hline & & & $\begin{array}{l}\text { 20. Price } \\
\text { A05 }\end{array}$ \\
\hline
\end{tabular}

